Atmos. Chem. Phys., 13, 10243-10269, 2013

www.atmos-chem-phys.net/13/10243/2013/

doi:10.5194/acp-13-10243-2013

(c) Author(s) 2013. CC Attribution 3.0 License.

\title{
Photosynthesis-dependent isoprene emission from leaf to planet in a global carbon-chemistry-climate model
}

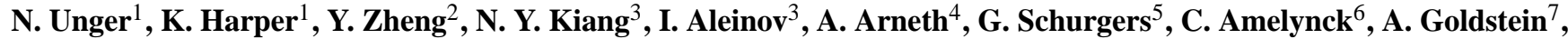

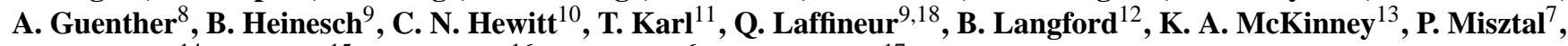 \\ M. Potosnak ${ }^{14}$, J. Rinne ${ }^{15}$, S. Pressley ${ }^{16}$, N. Schoon ${ }^{6}$, and D. Serça ${ }^{17}$ \\ ${ }^{1}$ School of Forestry and Environmental Studies, Yale University, New Haven, CT 06511, USA \\ ${ }^{2}$ Department of Geology and Geophysics, Yale University, New Haven, CT 06511, USA \\ ${ }^{3}$ NASA Goddard Institute for Space Studies, New York, NY 10025, USA \\ ${ }^{4}$ Karlsruhe Institute for Technology, Institute of Meteorology and Climate Research, Kreuzeckbahnstr. 19, 82467 \\ Garmisch-Partenkirchen, Germany \\ ${ }^{5}$ Department of Earth and Ecosystem Sciences, University of Lund, Lund, 22362, Sweden \\ ${ }^{6}$ Belgian Institute for Space Aeronomy, Ringlaan-3-Avenue Circulaire, 1180 Brussels, Belgium \\ ${ }^{7}$ Department of Environmental Science, Policy, and Management, University of California at Berkeley, \\ Berkeley, CA 94720, USA \\ ${ }^{8}$ National Center for Atmospheric Research, Boulder, CO, USA \\ ${ }^{9}$ Unité de Physique des Biosystèmes, Gembloux Agro-Bio Tech, University of Liège, Gembloux, Belgium \\ ${ }^{10}$ Lancaster University, Bailrigg, Lancaster, UK \\ ${ }^{11}$ University of Innsbruck, Institute of Meteorology and Geophysics, Innsbruck \\ ${ }^{12}$ Centre for Ecology and Hydrology, Midlothian, UK \\ ${ }^{13}$ Department of Chemistry, Amherst College, Amherst, Massachusetts, USA \\ ${ }^{14}$ DePaul University, Chicago, IL, USA \\ ${ }^{15}$ University of Helsinki, Helsinki, Finland \\ ${ }^{16}$ Washington State University, Pullman, WA, USA \\ ${ }^{17}$ Université Toulouse, Toulouse, France \\ ${ }^{18}$ Royal Meteorological Institute of Belgium, Ringlaan-3-Avenue Circulaire, 1180 Brussels, Belgium
}

Correspondence to: N. Unger (nadine.unger@yale.edu)

Received: 27 May 2013 - Published in Atmos. Chem. Phys. Discuss.: 4 July 2013

Revised: 5 September 2013 - Accepted: 15 September 2013 - Published: 22 October 2013

\begin{abstract}
We describe the implementation of a biochemical model of isoprene emission that depends on the electron requirement for isoprene synthesis into the FarquharBall-Berry leaf model of photosynthesis and stomatal conductance that is embedded within a global chemistry-climate simulation framework. The isoprene production is calculated as a function of electron transport-limited photosynthesis, intercellular and atmospheric carbon dioxide concentration, and canopy temperature. The vegetation biophysics module computes the photosynthetic uptake of carbon dioxide coupled with the transpiration of water vapor and the isoprene emission rate at the 30 min physical integration time
\end{abstract}

step of the global chemistry-climate model. In the model, the rate of carbon assimilation provides the dominant control on isoprene emission variability over canopy temperature. A control simulation representative of the present-day climatic state that uses 8 plant functional types (PFTs), prescribed phenology and generic PFT-specific isoprene emission potentials (fraction of electrons available for isoprene synthesis) reproduces $50 \%$ of the variability across different ecosystems and seasons in a global database of 28 measured campaign-average fluxes. Compared to time-varying isoprene flux measurements at 9 select sites, the model authentically captures the observed variability in the $30 \mathrm{~min}$ 
average diurnal cycle $\left(R^{2}=64-96 \%\right)$ and simulates the flux magnitude to within a factor of 2 . The control run yields a global isoprene source strength of $451 \mathrm{TgC} \mathrm{yr}^{-1}$ that increases by $30 \%$ in the artificial absence of plant water stress and by $55 \%$ for potential natural vegetation.

\section{Introduction}

Global terrestrial gross primary productivity (GPP) is the total amount of carbon dioxide $\left(\mathrm{CO}_{2}\right)$ removed from the atmosphere by plant photosynthesis. GPP is the largest flux in the global carbon cycle and is of fundamental importance to life on Earth as the basis for food and fiber. By absorbing an increasing amount of fossil fuel $\mathrm{CO}_{2}$, GPP provides a critical ecosystem service of climate protection in the Anthropocene (Ballantyne et al., 2012). Estimates of GPP center around $120 \mathrm{PgC} \mathrm{yr}^{-1}$ (Beer et al., 2010) although recent isotopic analysis supports a higher value of $150-175 \mathrm{PgC} \mathrm{yr}^{-1}$ (Welp et al., 2011). Land ecosystems return to the atmosphere an estimated $1 \%$ of GPP in the form of biogenic volatile organic compounds (BVOCs) (Guenther et al., 2012). This $>1 \mathrm{PgC} \mathrm{yr}^{-1}$ chemically reactive carbon flux is of comparable magnitude to the annual global net ecosystem production and an order of magnitude larger than the annual anthropogenic VOC source. The ecological and physiological roles of BVOCs are broad and range from abiotic and biotic stress functions to integrated components of carbon metabolism (Loreto and Schnitzler, 2010; Kesselmeier and Staudt, 1999). The dominant BVOC emitted is isoprene, amounting to half of the total annual flux of reactive carbon (Guenther et al., 2012). The biogenic isoprene flux is comparable to the total flux of methane including both biogenic and anthropogenic sources. The specific roles of isoprene emission are not fully understood but may be related to protection against heat and antioxidants. For instance, isoprene stabilizes chloroplastic membranes during high temperature events, allowing the plant's photosynthetic capacity to be maintained during rapid leaf temperature fluctuations caused by sun flecks in the canopy (Sharkey and Singsaas, 1995; Behnke et al., 2010). Isoprene reduces plant damage caused by ozone and reactive oxygen species (Vickers et al., 2009).

The chemical transformation of isoprene in the atmosphere has a profound effect on the distribution and variability of the key short-lived climate forcers: tropospheric ozone $\left(\mathrm{O}_{3}\right)$, secondary organic aerosol, and methane $\left(\mathrm{CH}_{4}\right)$ (Fiore et al., 2012). Thus, the isoprene flux is of central importance to understanding interactions between atmospheric chemistry and climate. Indeed, isoprene emission may have played an important role in the Earth system climate sensitivity in past greenhouse worlds (Beerling et al., 2011). While it is qualitatively perceived that human and/or natural perturbations to isoprene emission may provide a powerful lever on regional climate and even trigger feedbacks to global climate (Pitman et al., 2012), there is a lack of quantitative understanding of this critical ecosystem-chemistryclimate linkage. The main challenges have been the accurate model representation of the isoprene emission response to the complex, sometimes, opposing, influences of global change (Monson et al., 2007) and the development of appropriate coupled global carbon-chemistry-climate modeling frameworks.

Isoprene emission rate depends strongly upon ecosystem type with broadleaf trees and shrubs exhibiting the strongest emission potentials. Isoprene is produced in the chloroplast from precursors formed during photosynthesis. Isotopic labeling shows that about $70-90 \%$ of isoprene production is directly linked to photosynthesis, which provides the supply of energy, reducing power and carbon skeletons for inleaf biosynthesis (Delwiche and Sharkey, 1993; Karl et al., 2002; Affek and Yakir, 2003). The remaining isoprene production is associated with an older carbon source. Any single molecule of isoprene can include precursors from both newly assimilated and the older carbon source. In the laboratory and the field, the incomplete coupling to the photosynthetic flow is revealed in 4 ways: (1) the time lag between the onset of photosynthesis and isoprene emission, which is due to the effects of the growth environment on the expression of isoprene synthase e.g. (Kuzma and Fall, 1993; Sharkey and Loreto, 1993; Fuentes et al., 1999; Monson et al., 1994; Goldstein et al., 1998; Pressley et al., 2005); (2) the higher temperature optimum of isoprene production versus photosynthesis such that at high leaf temperatures the rates of isoprene production and photosynthesis are inversely correlated; (3) the initial short-term increase in isoprene emission under drought stress e.g. (Pegoraro et al., 2004, 2005, 2006). Under sustained drought stress, the isoprene emission rate does decrease according to the reduction in photosynthetic rate. Active upregulation of isoprene production during drought stress has been posited (Monson et al., 2007; Niinemets, 2010) but there remain unresolved issues regarding the isoprene emission response to drought (4) the isoprene emission rate has an inverse relationship in response to increasing atmospheric $\mathrm{CO}_{2}$ concentration (opposite to that observed for the photosynthetic $\mathrm{CO}_{2}$ assimilation rate), behavior known as the " $\mathrm{CO}_{2}$-inhibition effect" (Rosenstiel et al., 2003; Possell et al., 2004, 2005; Possell and Hewitt, 2011; Monson et al., 2007). Competition for carbon substrate has been offered as a mechanistic explanation for the $\mathrm{CO}_{2}$-inhibition effect (Rosenstiel et al., 2003; Wilkinson et al., 2009). Enhanced isoprene-related tolerance of heat and light stressed photosynthesis has been found at low but not high $\mathrm{CO}_{2}$ concentrations (Way et al., 2011). It has been hypothesized that isoprene biosynthesis evolved in a low $\mathrm{CO}_{2}$ climate state, which prompts the important question: what is the functional benefit of leaf isoprene production in a future high $\mathrm{CO}_{2}$ world?

Global isoprene emission models have been developed for application in chemistry-climate studies (Guenther et al., 
1995, 2006; Lathiére et al., 2006; Arneth et al., 2007; Pacifico et al., 2011). The most widely used approach to simulate interactive isoprene emission is to modify ecosystem-specific basal emission rates under standard conditions, either at the leaf or canopy level, with empirical functions in the form of serial multipliers that describe the observed emission response to specific environmental controls (light, temperature, soil moisture) (Guenther et al., 1991, 1995, 2006). This approach has been applied within prescribed static vegetation frameworks, for instance in the complex global canopy environment Model of Emissions of Gases and Aerosols from Nature (MEGAN) (Guenther et al., 2006); and within dynamic global vegetation model (DGVM) frameworks, for instance in the Organizing Carbon and Hydrology in Dynamic EcosystEms model (ORCHIDEE) (Lathiére et al., 2006) and in the Community Land Model (Heald et al., 2008). Similarly, the empirical functions that describe isoprene emission response to light and temperature at the leaf or canopy level have been directly embedded within global chemistryclimate and global chemistry-transport models (CCMs and CTMs) using prescribed static vegetation e.g. (Wu et al., 2008; Shindell et al., 2006; Horowitz et al., 2007). Current generation global CCMs and CTMs usually neglect the response of isoprene emission to soil moisture. Precipitation controls photosynthesis in more than $40 \%$ of vegetated land (Beer et al., 2010). It follows that water availability must play an important role in isoprene emission that will in turn affect the atmospheric composition and climate-air pollution interactions.

Medium to long-term changes of vegetation physiology and composition in response to global change drivers (climate change, $\mathrm{CO}_{2}$, land use), and increasing awareness of the complex mutual feedbacks between isoprene emission and regional climate sensitivity, make it necessary to link isoprene emission directly to the biological processes that affect emissions. To address this urgent need, a leaf-level isoprene emission model that depends on the electron requirement for isoprene synthesis (Niinemets et al., 1999) has been modified for implementation within DGVM frameworks including the Lund Potsdam Jena General Ecosystem Simulator (LPJ-GUESS) (Arneth et al., 2007), and the Joint UK Land Environmental Simulator (JULES) (Pacifico et al., 2011). Isoprene emissions generated in this way have been used in chemistry-climate modeling studies. For instance LPJ-GUESS isoprene emissions were applied off-line in the UM_CAM model to quantify the effects of the $\mathrm{CO}_{2}$ inhibition on future ozone predictions (Young et al., 2009), and JULES isoprene emissions have been applied on-line in the HadGEM2 Earth-system model to examine the sensitivity of isoprene emission to past and future global change and the implications for atmospheric chemistry (Pacifico et al., 2012).

Global modeling of carbon cycle-climate and chemistryclimate and interactions have evolved as entirely separate communities because $\mathrm{CO}_{2}$ is chemically unreactive in the atmosphere and because of the vast differences in the system integration time scales. There are many existing DGVMs whose contemporary global carbon cycle simulations have been extensively evaluated (Sitch et al., 2008; Schwalm et al., 2010). These models do not typically include on-line atmospheric chemistry. On the other hand, global chemistry-climate models normally rely on off-line prescribed vegetation input data sets. Our objective is to implement the biochemical leaf isoprene production scheme of (Niinemets et al., 1999) into on-line vegetation biophysics integrated within a global chemistry-climate model framework. To achieve this objective, we introduce the Yale-E2 global carbon-chemistry-climate model that is built around the NASA Goddard Institute for Space Studies (GISS) Model-E2 global climate model and features advanced biogeochemistry-climate interactions under separate development at Yale University.

The major goals of this study are (i) to describe the model and (ii) to evaluate the global scale model performance in the present climate state. The modeling methodology and isoprene emission algorithm are detailed in Sect. 2. In Sect. 3, we specify the control and sensitivity global simulations that are carried out for this work. Section 4 summarizes the global model results and presents the model evaluation including: summary of simulated global GPP and isoprene emission (Sect. 4.1), isoprene emission sensitivity to GPP and canopy temperature (Sect. 4.1.1), evaluation of global GPP and isoprene emission (Sect. 4.2), FLUXNET-derived global GPP (Sect. 4.2.1), GPP and latent heat seasonal cycle at 6 benchmark sites (Sect. 4.2.2), global database of campaign-average isoprene flux measurements (Sect. 4.2.3), time-varying isoprene emission through campaign periods (Sect. 4.2.4), isoprene and GPP diurnal cycle (Sect. 4.2.5). Discussion and conclusions are presented in Sect. 5.

\section{Methodology}

\subsection{Yale-E2 global carbon-chemistry-climate model}

Yale-E2 is built around the new generation IPCC AR5 version NASA Model-E2 global climate model (Schmidt et al., 2006) and incorporates interactive terrestrial ecosystems, a dynamic carbon cycle module, and 2-way coupling between the on-line vegetation and atmospheric chemistry. The model has flexible horizontal and vertical resolution. In this study, we apply $2^{\circ} \times 2.5^{\circ}$ latitude by longitude horizontal resolution with 40 vertical layers extending to $0.1 \mathrm{hPa}$. The vegetation submodel is embedded within the general circulation model that provides the key meteorological drivers for the vegetation physiology (Friend and Kiang, 2005). The landsurface hydrology submodel provides the grid cell level soil characteristics to the vegetation physiology. The well established gas-phase chemistry and aerosol modules are fully integrated, so that these components interact with each other 
Table 1. PFT-specific fractional coverage of global vegetated land area in the standard and SiB2 data sets (\%) and isoprene emission parameters used in Yale-E2 global carbon-chemistry-climate model. PFT-specific photosynthesis parameters are in Table A1.

\begin{tabular}{lcccc}
\hline PFT & SimCONT fraction $(\%)$ & SimSIB2 fraction $(\%)$ & $I_{\mathrm{S}}\left(\mu \mathrm{gCg}^{-1} \mathrm{~h}^{-1}\right)$ & $\varepsilon$ \\
\hline Tundra & 5.5 & 8.1 & 0 & 0.000 \\
Grass & 6.4 & 5.4 & 16 & 0.016 \\
Shrub & 3.2 & 8.2 & 16 & 0.055 \\
Savanna & 4.6 & 16.7 & 16 & 0.036 \\
Deciduous & 10.5 & 7.4 & 45 & 0.061 \\
Evergreen & 7.8 & 7.8 & 8 & 0.015 \\
Rainforest & 9.8 & 9.7 & 24 & 0.027 \\
Crop & 36.9 & 19.1 & 0 & 0.000 \\
\hline
\end{tabular}

and with the physics of the climate model (Bell et al., 2005; Shindell et al., 2006, 2013; Unger, 2011).

\subsubsection{Vegetation structure}

The vegetation is described using 8 plant functional types (PFTs): tundra, grass, shrub, savanna, deciduous, tropical rainforest, evergreen, and crop (Table 1). In this work, we apply two different vegetation cover data sets that have been converted to the 8 PFTs: (i) the standard atlas-based distribution in NASA Model-E2 (Matthews, 1983) and (ii) the Simple Biosphere Model II (SiB2) distribution based on the International Satellite Land Surface Climatology Project data initiative II (Loveland, 2009). The SiB2 data set provides its own crop cover. The standard data set consists of a map of the world's vegetation cover that would most likely exist in equilibrium with present-day climate and natural disturbance, in the absence of human activities (potential natural vegetation) onto which the crop fraction for each grid cell is overlaid. The crop fraction in each model grid cell is constructed from a harmonized gridded data set for the year 2000 (Hurtt et al., 2011). The crop cover is imposed by proportional decrease/increase of all the potential natural vegetation types in the grid cell fraction that is not occupied by crops and/or pasture. There is no right choice in how to implement the crop cover, but this approach is the most common treatment of crop cover in global climate modeling (de Noblet-Ducoudre et al., 2012). The fractional coverage of global vegetated land area by each PFT for the standard and SiB2 data sets is shown in Table 1 (bright and dark bare soil fractions not shown). In the standard data set, the fractional cover of crop PFT is about double that in SiB2 $(36.9 \%$ versus $19.1 \%)$ because tropical and subtropical land that is classified as crop PFT in the standard data set is classified as savanna and shrub PFTs in SiB2.

Leaf area index (LAI) for each PFT is prescribed according to regular seasonal sinusoidal variation between PFTspecific minimum and maximum seasonal LAI values that is insensitive to climate drivers or carbon balances (Rosenzweig and Abramopoulos, 1997; Friend and Kiang, 2005). A complete mechanistic understanding of the processes that control the development and senescence of foliage is not yet available such that the current state of phenology modeling may even be considered qualitative (Migliavacca et al., 2012; Richardson et al., 2013). We have made some improvements to the phenology for this work. Firstly, we have implemented a simplified crop phenology using a global data set of crop planting and harvesting dates (Sacks et al., 2010). The dominant crop type in each model grid cell was identified using a published data set of global crop maps and areal coverage (Monfreda et al., 2008). Then, a global model input file of mean plant date and harvest date was constructed for the grid cell's dominant crop type. The plant and harvest dates are recycled every simulation year. Secondly, a parameterization for phenological control (frost hardening) on photosynthetic capacity ( $V_{\mathrm{cmax}}$, Sect. 2.1.1) has been added for the evergreen PFT. $V_{\text {cmax }}$ is reduced in winter to protect against cold injury. Sensitivity to temperature determines the revival of photosynthetic capacity, hence the length of the growing season (Toivonen et al., 1991; Makela et al., 2004; Hanninen and Kramer, 2007). The onset of the growing season for the evergreen PFT can be delayed if temperature remains cold despite light being available.

The use of fixed canopy structures and phenology means that leaf mass is not driven by photosynthetic uptake of $\mathrm{CO}_{2}$ and a closed carbon cycle is not simulated. However, this version of the isoprene emission model can respond to elevated $\mathrm{CO}_{2}$ with regard to: $\mathrm{CO}_{2}$ fertilization, reduced stomatal conductance/increased water-use efficiency, $\mathrm{CO}_{2}$-inhibition, the temperature and precipitation responses of photosynthesis, but not phenological timing because the simulation does not account for the coupling of photosynthetic uptake to variability in growth. Application of LAI that is insensitive to climate may dampen the simulated interannual variability of isoprene emission in this model version.

\subsubsection{Canopy biophysics}

Each model PFT fraction in the vegetated part of each grid cell represents a single canopy. The model vertically stratifies each canopy into diffuse and direct light levels, and LAI profiles using an adaptive number of layers (typically 2-16) 
(Friend and Kiang, 2005). The well established MichealisMenten leaf model of photosynthesis (Farquhar et al., 1980; von Caemmerer and Farquhar, 1981) and the stomatal conductance model of Ball and Berry (Collatz et al., 1991) is used to compute the biophysical fluxes at the leaf level in each canopy layer based on appropriate parameters for each of the 8 PFTs from (Friend and Kiang, 2005) and the Community Land Model (Oleson et al., 2010) with updates from (Bonan et al., 2011) (Table A1). This coupled photosynthesis/stomatal conductance leaf model has previously been widely used to project terrestrial biosphere responses to global change. We summarize the model briefly here for transparency and completeness. The photosynthesis model assumes that the rate of net $\mathrm{CO}_{2}$ assimilation in the leaves of $\mathrm{C} 3$ plants is limited by one of three processes: (i) the capacity of the ribulose 1,5-bisphosphate (RuBP) carboxylaseoxygenase enzyme (Rubisco) to consume RuBP (Rubiscolimited photosynthesis); (ii) the capacity of the Calvin cycle and the thylakoid reactions to regenerate RuBP supported by electron transport (electron transport-limited photosynthesis); and (iii) the capacity of starch and sucrose synthesis to consume triose phosphates and regenerate inorganic phosphate for photo-phosphorylation (triose phosphate uselimited photosynthesis). Photosynthesis is electron transportlimited under low light conditions including overcast/cloudy conditions, at the start and end of the day, for shaded leaves and understory vegetation. The three processes are described as functions of the internal leaf $\mathrm{CO}_{2}$ concentration $\left(C_{i}\right)$ and/or the maximum carboxylation capacity at the optimal temperature, $25^{\circ} \mathrm{C},\left(V_{\text {cmax }}\right)$ (Table A1). Leaf stomata control for the uptake of $\mathrm{CO}_{2}$ versus the loss of water vapor $\left(\mathrm{H}_{2} \mathrm{O}\right)$. In the model, the stomatal conductance of $\mathrm{H}_{2} \mathrm{O}$ through the leaf cuticle is linearly related to the net rate of carbon assimilation and the relative humidity, and inversely related to the $\mathrm{CO}_{2}$ concentration at the leaf surface. The coupled system of photosynthesis, stomatal conductance and $\mathrm{CO}_{2}$ diffusive flux transport equations form a cubic in $C_{i}$ that is solved analytically (Baldocchi, 1994). A simple but realistic representation of soil water stress is included in the vegetation biophysics following the approach of Porporato et al. (2001). The algorithm reflects the relationship between soil water amount and the extent of stomatal closure ranging from no water stress to the soil moisture stress onset point $\left(\mathrm{s}^{*}\right)$ through to the wilting point $\left(\mathrm{s}_{\mathrm{wilt}}\right)$. Stomatal conductance is reduced linearly between the PFT-specific values of $\mathrm{s}^{*}$ and $\mathrm{s}_{\text {wilt }}$ (Table 1) based on the climate model's soil water volumetric saturation in 6 soil layers.

The leaf-level carbon and water fluxes are scaled up to the canopy level by integrating over each canopy layer. The land-surface model uses its own internal adaptive time step from $5 \mathrm{~s}$ to $15 \mathrm{~min}$ depending on the conditions. The carbon and water fluxes computed in the land-surface scheme are integrated over the climate model time step $(30 \mathrm{~min})$ for exchange with the model's atmosphere.

\subsubsection{Leaf isoprene production}

A leaf-level isoprene emission model that describes the constitutive production as a function of the electron transportlimited photosynthesis rate, $J_{\mathrm{e}}$, (Niinemets et al., 1999) has been integrated into the canopy biophysics scheme following modifications for global-scale modeling (Arneth et al., 2007). The leaf-level isoprene emission rate (I) in units of $\mu \mathrm{mol} \mathrm{m}{ }^{-2}$ [leaf] $\mathrm{s}^{-1}$ is calculated as follows:

$I=J_{e} \cdot \beta \cdot \kappa \cdot \tau \cdot \varepsilon$,

where $J_{\mathrm{e}}$ is the electron transport limited photosynthesis rate in units of $\mu \mathrm{mol} \mathrm{m} \mathrm{m}^{-2}$ [leaf $] \mathrm{s}^{-1}$. $J_{\mathrm{e}}$ is a linear function of the incident photosynthetically active radiation (PAR) and the internal leaf $\mathrm{CO}_{2}$ concentration $(\mathrm{Ci})$ :

$J_{\mathrm{e}}=a_{\text {leaf }} \cdot \operatorname{PAR} \cdot \alpha_{\mathrm{qe}} \cdot \frac{c_{i}-\Gamma^{*}}{c_{i}-2 \Gamma^{*}}$,

where $a_{\text {leaf }}$ is the leaf-specific light absorbance and $\alpha_{\mathrm{qe}}$ is the intrinsic quantum efficiency for photosynthetic $\mathrm{CO}_{2}$ uptake in the chlorophyll reaction system that absorbs PAR to drive the oxidation of water and the reduction of enzymes (photosystem II). $\alpha_{\mathrm{qe}}$ is a product of the fraction of absorbed light that reaches photosystem II and the $\mathrm{CO}_{2}$ per absorbed photon. $\Gamma^{*}$ is the $\mathrm{CO}_{2}$ concentration compensation point in the absence of non-photorespiratory respiration (Collatz et al., 1991).

The $\beta$ term in Eq. (1) translates the electron flux into isoprene equivalents given by Eq. (3):

$\beta=\frac{C_{i}-\Gamma^{*}}{6\left(4.67 C_{i}+9.33 \Gamma^{*}\right)}$.

A detailed description of the mechanistic origin of the coefficient values is given elsewhere (Niinemets et al., 1999; Pacifico et al., 2011).

The atmospheric $\mathrm{CO}_{2}$-inhibition is included via a simple parameterization $(\kappa)$ :

$\kappa=\frac{C_{i} \text { standard }}{C_{i}}$,

where $C_{i \_ \text {standard }}$ is the leaf internal $\mathrm{CO}_{2}$ concentration at standard atmospheric $\mathrm{CO}_{2}$, which is chosen to be the year 2000 global average value (370 ppmv). Equation (4) mimics the observed response to both short-term and long-term changes in $C_{i}$ (Wilkinson et al., 2009; Heald et al., 2009). For example, short-term reductions in $C_{i}$ due to stomatal closure under drought conditions imply increases in $\kappa$, while the long-term effects of increasing (decreasing) atmospheric $\mathrm{CO}_{2}$ imply decreases (increases) in $\kappa$.

The temperature relationship $(\tau)$ in the algorithm accounts for the difference in temperature optimum between photosynthesis and isoprene synthase:

$\tau=\exp \left[0.1\left(T-T_{\text {ref }}\right)\right]$, 
where $T=$ leaf temperature and $T_{\text {ref }}=$ standard temperature condition $\left(30^{\circ} \mathrm{C}\right)$. The temperature optimum for isoprene synthase is about $40^{\circ} \mathrm{C}$ (Guenther et al., 1991). Equation (5) does not simulate a temperature optimum after which isoprene emission rate decreases with further increases in temperature. Such high temperature conditions in isoprene emitting biomes rarely occur in nature at large ecosystem scales. Canopy-scale temperatures of this magnitude may occur under severe drought stress conditions when transpiration is significantly reduced. Yale-E2 uses the canopy temperature (not air temperature) in Eq. (5), which represents a significant departure from other CCMs and CTMs that drive interactive isoprene emissions with surface air temperature. Yale-E2 intrinsically captures the effects of changing stomatal conductance on canopy energy balance, which affects the canopy temperature, and thus the isoprene emission rate. In future and past hot greenhouse worlds, plant photosynthesis may acclimate to the higher temperatures (Arneth et al., 2012). This plastic adjustment of photosynthesis will indirectly impact isoprene emission. Whether the temperature optimum for isoprene synthase will similarly shift in warmer climates is not known.

$\varepsilon$ is the PFT-specific fraction of electrons available for isoprene synthesis or isoprene emission potential and parallels the use of a PFT-specific leaf-level isoprene emission capacity in Guenther et al. $(1991,1995)$. To calculate $\varepsilon$, we make use of available generic PFT-specific standard (or basal) leaf isoprene emission rates $\left(I_{\mathrm{S}}\right)$ in $\mu \mathrm{gC} \mathrm{g}^{-1}[\mathrm{leaf}] \mathrm{h}^{-1}$ based on recommendations from a wide range of observations (Table 1). Standard conditions are defined as: surface air temperature $=30^{\circ} \mathrm{C}$ and $\mathrm{PAR}=1000 \mu \mathrm{mol} \mathrm{m}^{-2} \mathrm{~s}^{-1}$. Again, we assume that atmospheric $\mathrm{CO}_{2}$ concentration $=370 \mathrm{ppm}$ under standard conditions. $I_{\mathrm{S}}$ must be converted to appropriate units of leaf area using the model values of specific leaf area (SLA), the amount of light-capturing surface area that is deployed with a given investment of dry mass in units of $\mathrm{m}^{2}$ [leaf] $\mathrm{g}^{-1}$ [leaf]. SLA is intimately connected to the resource use economy of the plant (Milla and Reich, 2007). Then, $\varepsilon$ is computed for each PFT by substituting $I=I_{\mathrm{S}}$ into Eq. 1) under standard conditions. The crop and tundra PFTs are non-emitting for isoprene in this model although recently, isoprene emission has been observed from a tundra ecosystem (Potosnak et al., 2013). Deciduous, shrub and rainforest PFTs maintain the highest fraction of electrons available for isoprene synthesis (Table 1). In the current model, $\varepsilon$ does not vary with time of day or season (Niinemets et al., 2010a, c) or through the canopy (Niinemets et al., 2010b). Many plant species in temperate and boreal ecosystems exhibit delayed onset of isoprene emission after the leaf development (Grinspoon et al., 1991; Hakola et al., 1998; Olofsson et al., 2005). Leaf age effects have been included in other global isoprene emission models using simplistic functions, for example involving growing degree-day temperature (Arneth et al., 2007; Guenther et al., 2006; Lathiére et al., 2006).
Scaling of isoprene emission from the leaf to the canopy uses the canopy vertical stratification and integration scheme as described in Sect. 2.1.2. The canopy-level isoprene fluxes are passed to the model's atmosphere through the landsurface scheme on the 30 min climate model time step.

\section{Simulations}

We apply Yale-E2 in an atmosphere-only configuration driven by sea surface temperatures and sea ice cover prescribed according to decadal average monthly varying observations for 1996-2005 from the HadSST2 data set (Rayner et al., 2006). Atmospheric $\mathrm{CO}_{2}$ is prescribed to a uniform concentration of $370 \mathrm{ppmv}$ representative of approximately year 2000 levels. We perform a control simulation ("SimCONT") that uses the standard atlas-based vegetation cover distribution in NASA Model-E2 (Matthews, 1983). In addition, we perform three sensitivity simulations described in Table 2 . Sensitivity simulation "SimSiB2" uses an alternate vegetation cover data set based on the $\mathrm{SiB} 2$ distribution. We perform a simulation "SimH2O" in which the plant water stress function in the biophysics module is artificially switched off to quantify the effects of water limitation on isoprene emission rate. In order to explore the extent of human land cover change impacts on isoprene, a simulation "SimPNV" is run that uses the potential natural vegetation cover data set (i.e. without the crop PFT superimposed). The control and sensitivity simulations are each run for 10 model years that are averaged for the evaluation analyses. The model version applied in this study outputs the total isoprene (and GPP) in each grid cell and does not characterize PFT-specific attribution. The model's carbon fluxes (GPP and isoprene) are present-day climatologies and do not pertain to any specific meteorological year.

\section{Results}

\subsection{Simulated global GPP and isoprene emission}

The global annual average isoprene emission and GPP flux for each simulation are reported in Table 2. Global GPP in SimCONT and SimSiB2 $\left(124-126 \mathrm{PgC} \mathrm{yr}^{-1}\right)$ is in reasonable agreement with current understanding of the contemporary carbon cycle budget. The global isoprene source in SimCONT and SimSiB2 $\left(451-498 \mathrm{TgC}^{-1}\right)$ is consistent with previous global estimates of $400-700 \mathrm{TgC}^{-1}$ (Guenther et al., 2006). This good agreement is because the model applies widely used generic PFT-specific $I_{\mathrm{S}}$ values to derive the PFT-specific fraction of electrons for isoprene synthesis $(\varepsilon)$ as previously alluded (Arneth et al., 2008). The spatial distribution of annual and seasonal average GPP and isoprene emission are shown in Fig. 1a, b, respectively. The major isoprene emitting biome is tropical rainforest that provides a perennial reactive carbon flux to the atmosphere, but the 
Table 2. Summary of global annual average carbon fluxes in the model runs. In total 10 model run years are included in the annual average for each simulation. All runs use 1996-2005 average monthly varying SSTs and sea ice. Uncertainty values are based on the standard error relative to internal climate model variability $(n=10 \mathrm{yr})$.

\begin{tabular}{|c|c|c|c|c|}
\hline Simulation & Land cover & Description and purpose & $\begin{array}{l}\mathrm{GPP} \\
\left(\mathrm{PgC} \mathrm{yr}^{-1}\right)\end{array}$ & 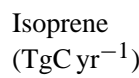 \\
\hline SimCONT & Standard, Matthews (1983) & Present Climate Control & $124 \pm 2$ & $451 \pm 5$ \\
\hline SimSiB2 & SiB2, Loveland (2009) & Test impact of alternate vegetation cover data set & $126 \pm 2$ & $498 \pm 5$ \\
\hline $\mathrm{SimH} 2 \mathrm{O}$ & Standard, Matthews (1983) & $\begin{array}{l}\text { Test impact of water stress function } \\
\text { in vegetation biophysics }\end{array}$ & $155 \pm 1$ & $592 \pm 3$ \\
\hline SimPNV & Standard + no human alteration, Matthews (1983) & Test impact of potential natural vegetation & $137 \pm 2$ & $701 \pm 10$ \\
\hline
\end{tabular}
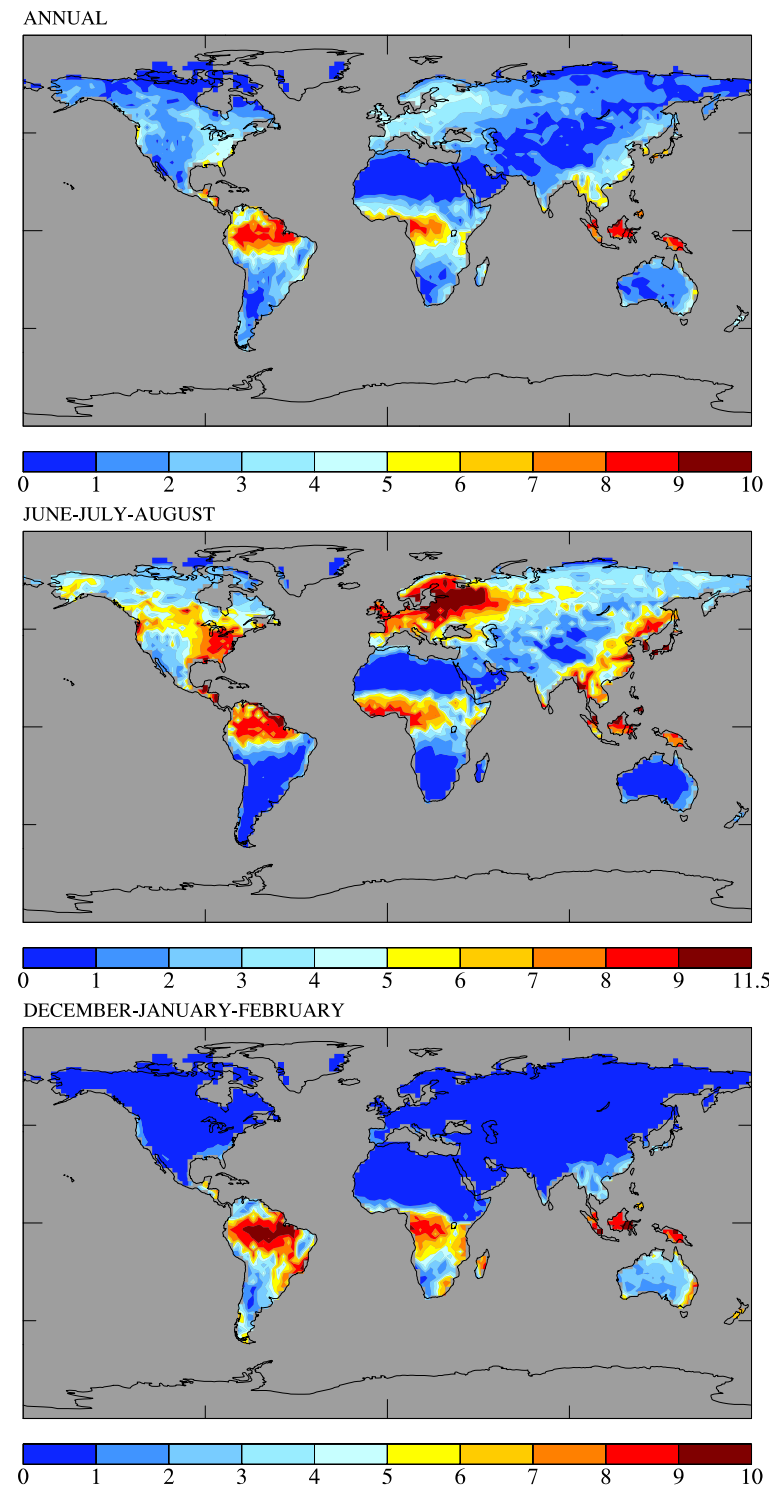

Fig. 1a. Spatial distribution of annual and seasonal average modeled GPP in $\mathrm{gC} \mathrm{m}^{-2}$ day $^{-1}$ in the control run SimCONT.
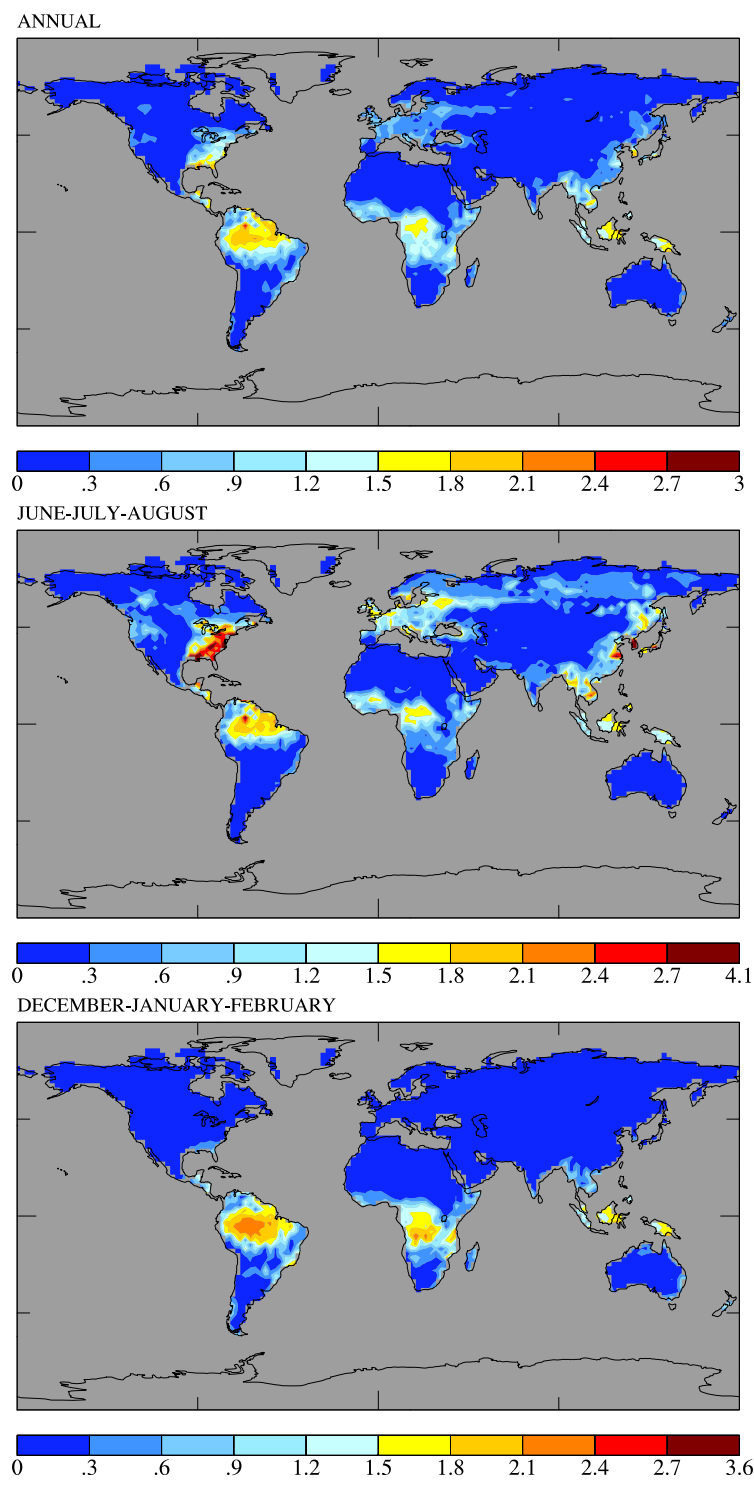

Fig. 1b. Spatial distribution of annual and seasonal average modeled isoprene emission in $\mathrm{mgC} \mathrm{m}^{-2} \mathrm{~h}^{-1}$ in the control run SimCONT. 
growing season isoprene emission in the eastern US rivals the tropical emission in magnitude.

Globally, the isoprene source strength is $10 \%$ higher in SimCONT than SimSiB2 whereas GPP is only $\sim 1 \%$ higher. The different response sensitivity of isoprene and GPP to the vegetation cover data set arises because of the differences in the classification of crop PFT between data sets, and all PFTs assimilate carbon but the crop PFT is non-emitting for isoprene. Previous studies have suggested an even higher sensitivity of the global isoprene source (20-30\%) to the model's vegetation cover data sets for a given algorithm (Guenther et al., 2006; Pfister et al., 2008; Arneth et al., 2011). In the artificial absence of plant water stress, GPP increases by $25 \%$ with a similar increase in global isoprene emission ( $30 \%)$. Similarly, the MEGAN model suggested that accounting for soil moisture stress in the present climate state leads to a 20-30\% reduction in the global isoprene source strength (Müller et al., 2008). The response to potential natural vegetation cover is more dramatic: the global isoprene source increases by $55 \%$ whereas GPP increases by only $10 \%$. The strong sensitivity of isoprene to potential natural vegetation cover suggests significantly higher isoprene emission in pre-human disturbance conditions and large variability in isoprene emission due to human land cover change. In the most recent community assessment of anthropogenic ozone radiative forcing led by the Atmospheric Chemistry and Climate Model Intercomparison Project, only 4 of 15 participating state-of-the-science global chemistry-climate models included climate-sensitive isoprene emission (Young et al., 2013). Those 4 models all projected a small increase in isoprene emission from preindustrial to present-day in response to temperature change. 9 out of 15 models prescribed isoprene emission and used the same off-line input data for preindustrial and present-day.

There are substantial regional differences in isoprene emission between the sensitivity and control simulations (Fig. 2). Annual average isoprene emission in Europe and the southeastern US is smaller in SimCONT than SimSiB2 by $\sim 0.5-1.5 \mathrm{mgC} \mathrm{m}^{-2} \mathrm{~h}^{-1}$. In the tropical biome, SimCONT simulates higher annual average isoprene emission than Sim$\mathrm{SiB} 2$ by $\sim 0.3-1 \mathrm{mgC} \mathrm{m}^{-2} \mathrm{~h}^{-1}$. The presence of plant water stress affects isoprene in all emitting biomes. In the artificial absence of plant water stress, large increases in the annual average isoprene emission $\left(\sim 1 \mathrm{mgC} \mathrm{m}^{-2} \mathrm{~h}^{-1}\right)$ occur in the tropics, southeastern US, and the boreal region. Potential natural vegetation cover implies additional isoprene emission $\left(\sim 2 \mathrm{mgC} \mathrm{m}^{-2} \mathrm{~h}^{-1}\right.$ on the annual average) in the eastern US, Europe and the tropics on land that has zero emission capacity in the standard cover data set.

\subsubsection{Isoprene emission sensitivity to GPP and canopy temperature}

We have applied multiple linear regression to compute the standardized regression coefficients between isoprene emis-
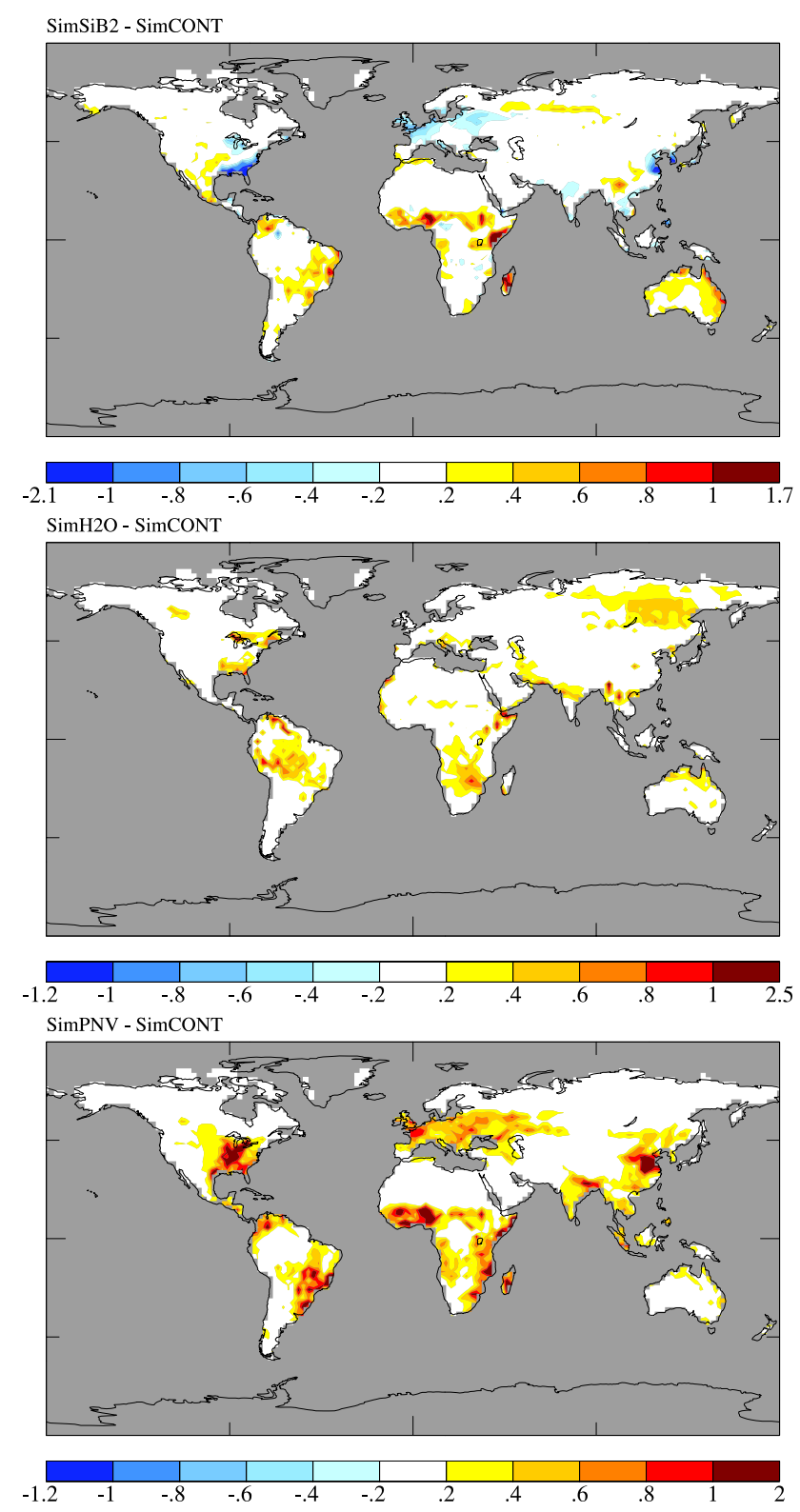

Fig. 2. Difference in simulated annual average isoprene emission relative to the control simulation for an alternative vegetation cover map (top), in the artificial absence of water stress (middle), and for potential natural vegetation cover (bottom). Units are $\mathrm{mgC} \mathrm{m}^{-2} \mathrm{~h}^{-1}$.

sion and the key drivers (GPP and canopy temperature) in boreal summer for SimCONT and SimH2O (Fig. 3). The coefficients represent the partial regression coefficients in units of standard deviation, such that they can be directly compared with each other to determine the relative importance of the different driving variables (Fig. 3). The leaf-level isoprene emission rate is linearly related to the electron transport-limited photosynthesis rate, $J_{\mathrm{e}}$ (Eq. 1). Above $30^{\circ} \mathrm{C}$, the isoprene emission follows an 

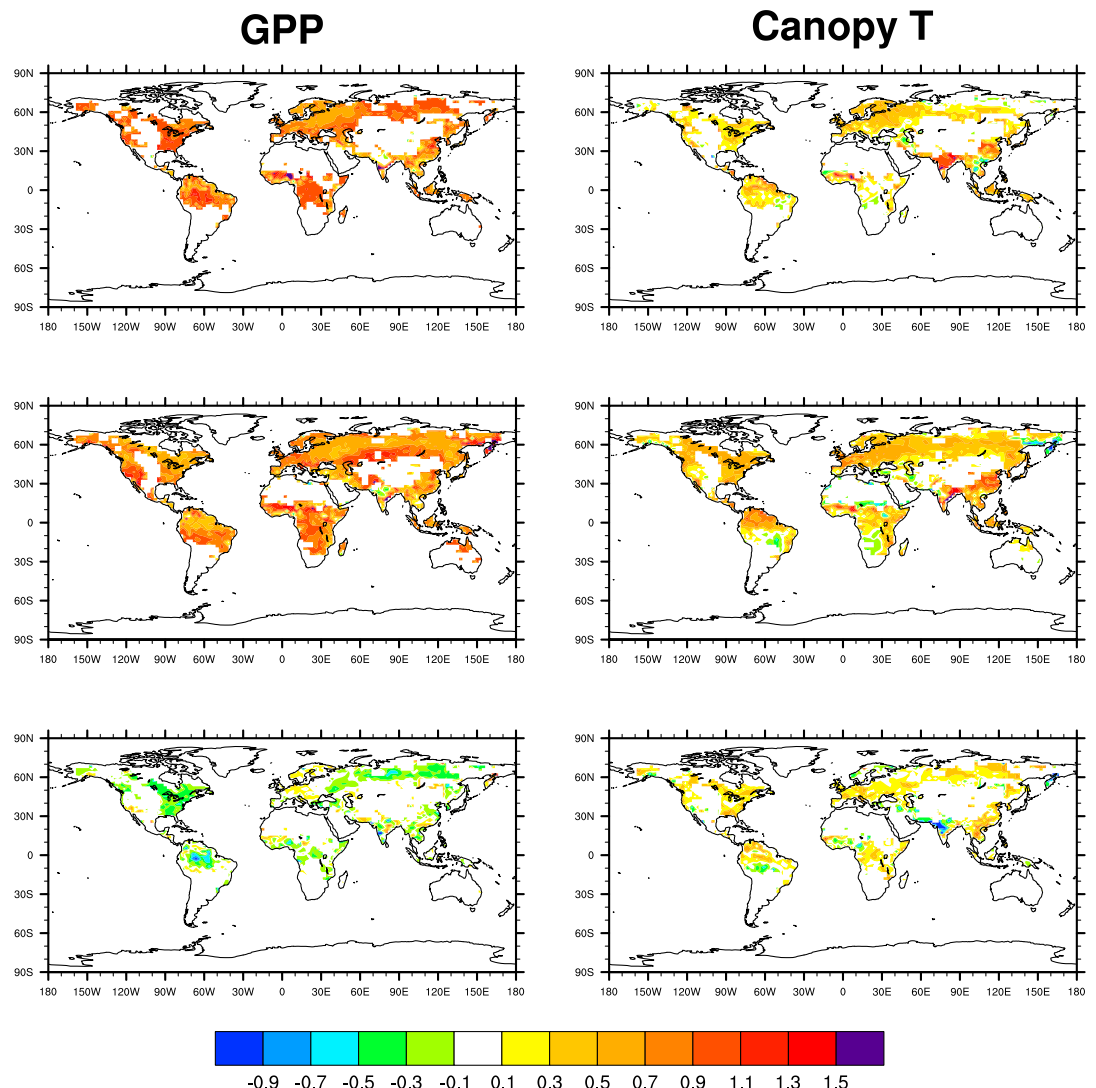

Fig. 3. Standardized regression coefficients between isoprene emission and the key drivers GPP (left column) and canopy temperature (right column). Results shown are averages for June-July-August in SimCONT (top row), SimH2O (middle row), and the difference [SimH2O SimCONT] (bottom row).

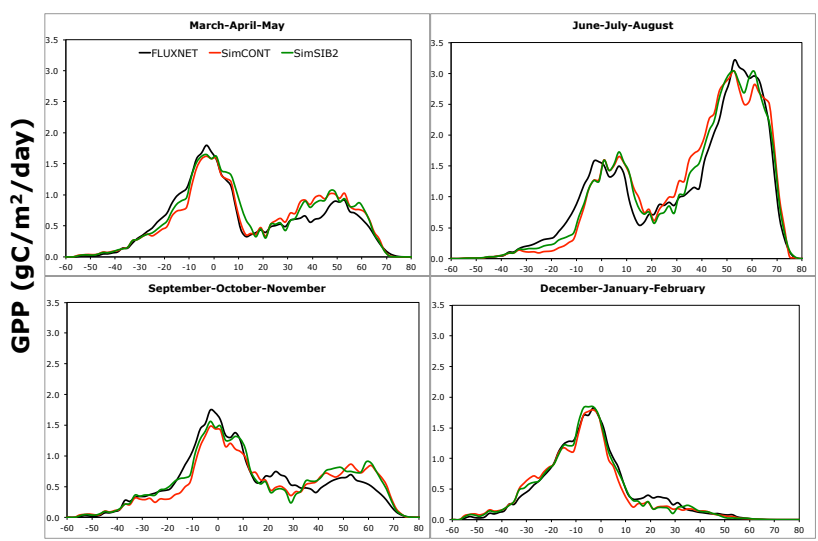

Latitude $\left({ }^{\circ}\right)$

Fig. 4. Seasonal zonal average GPP simulated in SimCONT and SimSiB2 compared to the FLUXNET-derived data set $\left(\mathrm{gC} \mathrm{m}^{-2} \mathrm{day}^{-1}\right)$.

exponential relationship with temperature (Eq. 5). In the control run (SimCONT), the standardized regression coefficient is about a factor of 2 higher for GPP than canopy tem- perature everywhere except the most severely water-limited ecosystems (e.g. Indian subcontinent). Thus, GPP dominates over canopy temperature in controlling isoprene emission variability in most regions of the world in the model. In the absence of water stress ( $\mathrm{SimH} 2 \mathrm{O})$, the standardized regression coefficients for canopy temperature increase by around $30 \%$ while the standardized regression coefficients for GPP decrease by around $30 \%$, relative to the control run (SimCONT). However, GPP still exerts the dominant control over canopy temperature in controlling isoprene emission variability in this model. The presence of plant water stress reduces the sensitivity of isoprene emission to canopy temperature because drought conditions are frequently associated with high temperatures that result in a decrease in GPP and therefore isoprene emission. Two important corollaries are that (1) variability in isoprene emission is largely determined by the same factors that determine GPP variability (temperature, precipitation, the availability of water and nutrients, disturbance) and (2) isoprene emission algorithms that do not account for the impacts of water availability may overestimate the sensitivity of isoprene emission to canopy (and/or surface air) temperature. Since a global observational data set of isoprene emission is not available, we are unable to 
explore these relationships at large regional scales in the real world.

\subsection{Evaluation of global GPP and isoprene emission}

Direct large-scale measurements of photosynthesis and isoprene emission do not exist. The FLUXNET network of tower sites continuously measures the $\mathrm{CO}_{2}$ net ecosystem exchange (NEE) flux between the biosphere and atmosphere using the eddy covariance technique (Baldocchi et al., 2001). NEE is the imbalance between photosynthesis and ecosystem respiration. Photosynthesis is zero at night, which allows for a temperature-based predictor of the respiration that can be used to extrapolate GPP from the day time NEE. Isoprene fluxes have been measured during short campaigns at several FLUXNET sites. Our approach to evaluate the global model performance is to compare the simulated GPP and isoprene emission rate to available above-canopy flux tower measurements of the carbon fluxes. Recent research has shown that space-based observations of formaldehyde ( $\mathrm{HCHO}$ ) columns may be a useful proxy of surface isoprene emissions across broader ecosystem and regional scales (Palmer et al., 2003; Barkley et al., 2009). We elect not to use this approach here because of the inherent limitation that an a priori isoprene emission model is necessary to interpret the $\mathrm{HCHO}$ satellite columns (Barkley et al., 2012).

Because of the different spatial and temporal scales of the model output versus the observations, comparing to point measurements from flux towers represents an extremely stringent performance test and a number of caveats must be emphasized. Firstly, the model GPP and isoprene emission are extracted for the single grid cell $\left(2^{\circ} \times 2.5^{\circ}\right.$ latitude by longitude) in which the flux tower site is located. Our rationale is that, while the typical eddy covariance footprint is small $\left(\sim 1 \mathrm{~km}^{2}\right)$, the trace gas flux variability at the flux towers is often representative over much larger spatial scales because of the spatial coherence of climate anomalies (Ciais et al., 2005). Secondly, the model parameters are not tuned in any way to the local site vegetation properties. The model grid cell level output is based entirely on the vegetation structure and soil properties in Yale-E2 and not the flux tower site data. Finally, the point measurements are obtained at flux towers during specific meteorological periods. The model output represents $10 \mathrm{yr}$ average climatological GPP and isoprene emission rates (and meteorological variables) at the site locations, which do not necessarily reflect the exact local weather conditions that occurred during the observation period. Since the climate model has not been forced to the observed meteorology during the measurement periods, the model cannot be expected to reproduce day-today variability in the isoprene emission and GPP. Specifically for isoprene, the measurements are canopy exchange fluxes whereas the current model configuration does not include isoprene loss through the canopy. However, canopy loss is likely less than $10 \%$ of the total emission (Karl et al., 2004; Rinne et al., 2012). Based on the above caveats, we posit that the most important diagnostic quantities in this model/measurement comparison are: zonal average and seasonal cycle for GPP flux, and campaign-average variability across different ecosystems and diurnal cycle for isoprene emission. Focusing on these diagnostic quantities does provide for valuable insights into the global climate model's strengths and weaknesses. Typical measurement uncertainties associated with the eddy flux technique are about $\pm 30 \%$.

\subsubsection{FLUXNET-derived global GPP}

We compare the model simulated GPP (SimCONT and Sim$\mathrm{SiB} 2)$ to a global GPP data set that has been generated by data orientated diagnostic upscaling of site-derived GPP from FLUXNET (Beer et al., 2010; Jung et al., 2011; Bonan et al., 2011). The model runs reproduce the seasonal zonal average variability in the FLUXNET-derived data set with remarkable fidelity (Fig. 4). Based on linear regression, the model runs capture $\geq 89 \%$ of the variability in the zonal seasonal average FLUXNET-derived data set. The model runs perform best in the summer and winter seasons $(\geq 93 \%$ of the variability). SimSiB2 demonstrates slightly superior performance over SimCONT. The Northern Hemisphere (NH) June-July-August maximum at $50^{\circ}-60^{\circ} \mathrm{N}$ in the deciduous and crop biomes is well reproduced by the model (to within $10 \%$ ). In March-April-May and September-OctoberNovember, the model underestimates tropical GPP and overestimates GPP in the $\mathrm{NH}$ mid-latitudes between $35^{\circ}-60^{\circ} \mathrm{N}$ by around $10 \%$. Overall, the comparison results provide confidence in the model's ability to simulate the magnitude and zonal average variability in GPP.

\subsubsection{GPP and latent heat seasonal cycle at 6 benchmark sites}

A benchmarking system of seasonal FLUXNET data at select sites has been constructed for evaluation of the seasonal cycle of carbon and water biophysical fluxes in global modeling frameworks (Blyth et al., 2011). The characteristics of the 6 benchmark sites that are relevant for isoprene emission are described in Table 3. At the Hyytiala, Harvard and Santarem sites, the dominant vegetation PFT in the model grid cell is consistent with the FLUXNET tower site. At Morgan Monroe and Tharandt, the dominant model PFT in the grid cell is crop versus deciduous and evergreen, respectively at the FLUXNET tower sites. The Kaamanen FLUXNET tower site is wetland/woody savanna in reality whereas the standard cover is predominantly grass PFT in this model grid cell, and the $\mathrm{SiB} 2$ cover is a mixture of evergreen, deciduous and shrub PFTs.

The climatological models capture the GPP seasonality at the 6 sites reasonably well (Fig. 5a). We provide root mean square bias (RMSE) as the diagnostic metric (Table 3). All model climatologies overpredict at both $\mathrm{NH}$ high latitude 
Table 3. Summary of FLUXNET benchmark site characteristics, model vegetation cover fractions for the grid cell in which the site is located and model performance in terms of RMSE range across the model runs. Td=tundra; $\mathrm{G}=$ grass; $\mathrm{Sh}=\mathrm{shrub} ; \mathrm{S}=\mathrm{savanna}$; $\mathrm{D}=\mathrm{deciduous}$; $\mathrm{T}=$ tropical rainforest $\mathrm{E}=$ evergreen; and $\mathrm{C}=$ crop.

\begin{tabular}{|c|c|c|c|c|c|c|c|}
\hline \multirow[b]{2}{*}{ Name } & \multicolumn{2}{|r|}{ Site characteristics } & \multirow[b]{2}{*}{ Location } & \multicolumn{2}{|c|}{ Vegetation cover fraction $(\%)$} & \multicolumn{2}{|c|}{ RMSE } \\
\hline & Data year & Ecosystem Type & & SimCONT & SimSiB2 & $\begin{array}{c}\text { GPP } \\
\left(\mu \mathrm{mol} \mathrm{m}{ }^{2} \mathrm{~s}^{-1}\right)\end{array}$ & $\begin{array}{c}\text { Latent Heat } \\
\left(\mathrm{Wm}^{-2}\right)\end{array}$ \\
\hline Kaamanen & 2002 & Wetland/woody savanna & $69.1^{\circ} \mathrm{N}, 27.3^{\circ} \mathrm{E}$ & G:D 80/10 & E:Sh:D:Td:S:C 40/31/17/9/3 & $1.3-1.5$ & $7.4-9.0$ \\
\hline Hyytiala & 2000 & Evergreen needleleaf & $61.8^{\circ} \mathrm{N}, 24.3^{\circ} \mathrm{E}$ & E:D:C 35/34/31 & E:C:D 75/19/5 & $1.4-1.7$ & $12.7-14.4$ \\
\hline Morgan Monroe & 2002 & Deciduous broadleaf & $39.3^{\circ} \mathrm{N}, 86.4^{\circ} \mathrm{W}$ & C:D 51/49 & $C: D 67 / 31$ & $1.7-1.8$ & $20.5-21.6$ \\
\hline Harvard & 1999 & Deciduous broadleaf & $42.5^{\circ} \mathrm{N}, 72.2^{\circ} \mathrm{W}$ & D:C $97 / 3$ & D:E:C 79/16/5 & $1.9-2.6$ & $24.0-25.6$ \\
\hline Tharandt & 1999 & Evergreen needleleaf & $51.0^{\circ} \mathrm{N}, 13.6^{\circ} \mathrm{E}$ & C:E:D 51/25/24 & C:D:E 82/15/2 & $2.2-3.4$ & $14.4-16.4$ \\
\hline Santarem Km67 & 2003 & Tropical evergreen broadleaf & $2.9^{\circ} \mathrm{S}, 55.0^{\circ} \mathrm{W}$ & $\mathrm{T}: \mathrm{C} 94 / 6$ & T:S:E 87/7/3 & $0.4-1.0$ & $6.1-10.5$ \\
\hline
\end{tabular}

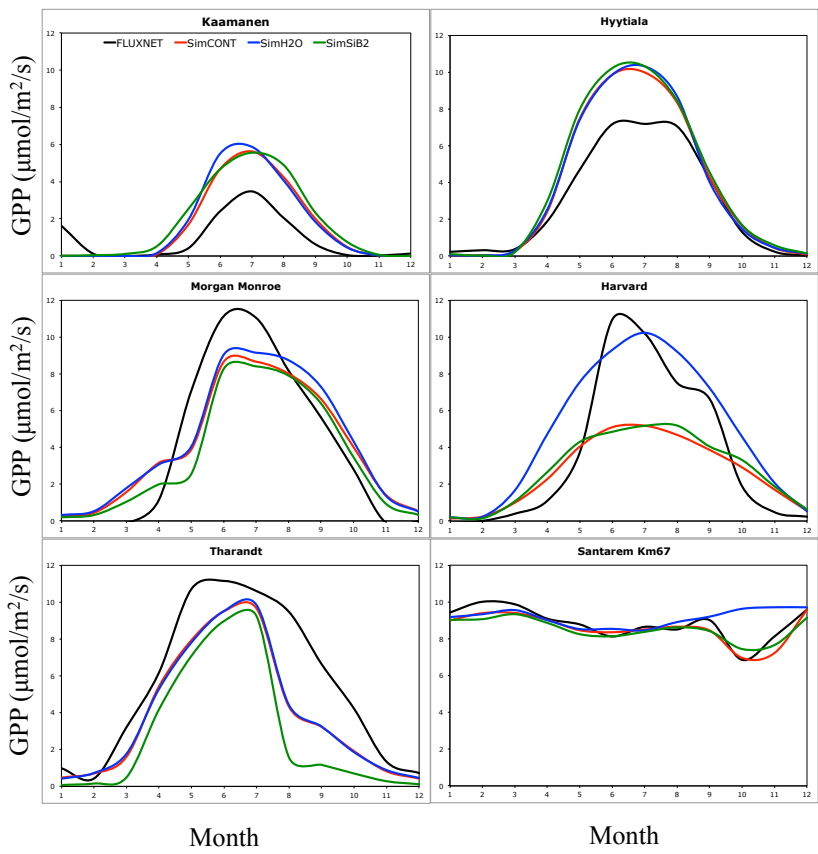

Fig. 5a. Comparison of eddy-derived and modeled monthly average GPP fluxes at 6 FLUXNET sites $\left(\mu \mathrm{molC} \mathrm{m}^{-2} \mathrm{~s}^{-1}\right)$.

sites (Kaamanen and Hyytiala) and underpredict at NH midlatitude sites (Morgan Monroe, Harvard and Tharandt). The model demonstrates skillful ability to reproduce the GPP flux at the tropical site (Santarem). SimCONT and SimSiB2 capture the observed GPP reduction in the dry season that is over predicted in the artificial absence of water stress ( $\mathrm{SimH} 2 \mathrm{O})$. The model's ability to reproduce the magnitude of summer GPP at Harvard is improved in the absence of water stress (SimH2O) but that configuration gives too high GPP in the spring and fall.

Previous analyses of FLUXNET measurements at a wide range of sites found a strong linkage between carbon gain and water loss for all biomes integrated over the year (Law et al., 2002). Figure $5 \mathrm{~b}$ compares the modeled and measured latent heat (evaporative) fluxes at each of the 6 FLUXNET sites. RMSE values are shown in Table 4. Yale-E2 satisfactorily
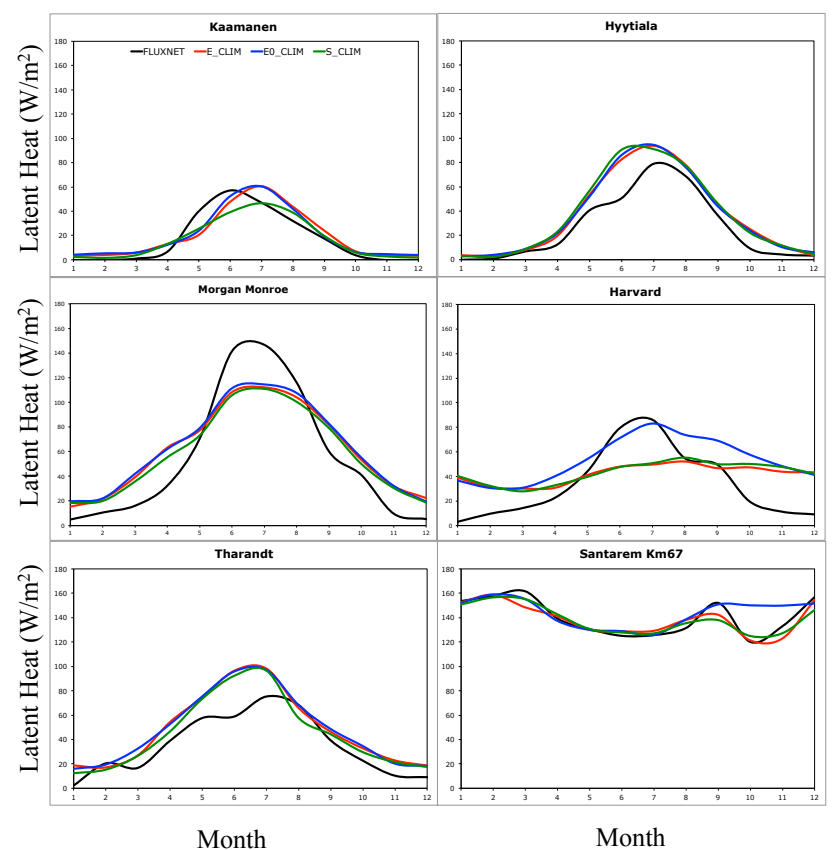

Fig. 5b. Comparison of measured and modeled latent heat flux at 6 FLUXNET sites $\left(\mathrm{W} \mathrm{m}^{-2}\right)$.

captures the seasonal cycle in latent heat flux at all sites, except at Harvard. Again, artificially turning off the water stress function does appear to improve the model's latent heat simulation at the Harvard site. The model's high values of latent heat outside of the growing season are due to the grid cell having $25 \%$ water coverage.

The model/measurement comparison of the GPP seasonal cycle at the 6 benchmark sites permits reasonable confidence in the model's biophysics for the simulation of isoprene emission. Based on the model GPP biases alone, the model may be expected to overestimate isoprene emission at $\mathrm{NH}$ high latitudes, underestimate at $\mathrm{NH}$ mid-latitudes, and perform well in the tropics. 
Table 4. Description of the 28 campaign-average above-canopy isoprene flux measurements collected between 1995-2010 across a wide range of ecosystem types, regions and seasons that comprise the benchmark global database. Codes for model vegetation fractions are: $\mathrm{Td}=$ tundra $\mathrm{G}=$ grass; $\mathrm{Sh}=$ shrub; $\mathrm{S}=$ savanna $\mathrm{D}=$ deciduous; $\mathrm{T}=$ tropical rainforest $\mathrm{E}=$ evergreen; and $\mathrm{C}=\mathrm{crop}$.

\begin{tabular}{|c|c|c|c|c|c|c|}
\hline \multirow[b]{2}{*}{ Identifier } & \multirow[b]{2}{*}{ Ecosystem } & \multicolumn{2}{|c|}{ Measurement sites } & \multirow[b]{2}{*}{ Reference } & \multicolumn{2}{|c|}{ Model grid cell vegetation fractions } \\
\hline & & Date & Location & & Standard & $\mathrm{SiB} 2$ \\
\hline Santarem & Rainforest & $07 / 2000$ & $2.9^{\circ} \mathrm{S}, 55^{\circ} \mathrm{W}$ & Rinne et al. (2002) & $\mathrm{T}: 94$ & T/Sv/E: $87 / 8 / 4$ \\
\hline Manaus & Rainforest & $07 / 2001$ & $2.35^{\circ} \mathrm{S}, 60^{\circ} \mathrm{W}$ & Kuhn et al. (2007) & T: 99 & T/Sv: $89 / 5$ \\
\hline Manaus & Rainforest & $09 / 2004$ & $2.6^{\circ} \mathrm{S}, 60^{\circ} \mathrm{W}$ & Karl et al. (2007) & T: 99 & $\mathrm{~T} / \mathrm{Sv}: 89 / 5$ \\
\hline Costa Rica & Rainforest & $04 / 2003$ & $10^{\circ} \mathrm{N}, 84^{\circ} \mathrm{W}$ & Karl et al. (2004) & T/C: $82 / 18$ & T/C: 74/14 \\
\hline Costa Rica & Tropical lowland & $10 / 1999$ & $10^{\circ} \mathrm{N}, 84^{\circ} \mathrm{W}$ & Geron et al. (2002) & T/C: $82 / 18$ & T/C: $74 / 14$ \\
\hline Malaysia & Rainforest & $11 / 2003$ & $3^{\circ} \mathrm{N}, 102^{\circ} \mathrm{E}$ & Saito et al. (2008) & T/C: 79/21 & C/T/D: 45/27/16 \\
\hline Borneo & Rainforest & $04 / 2008$ & $5^{\circ} \mathrm{N}, 118^{\circ} \mathrm{E}$ & Langford et al. (2010a) & T/C: $87 / 13$ & T/E: 78/15 \\
\hline Borneo & Rainforest & $06-07 / 2008$ & $5^{\circ} \mathrm{N}, 118^{\circ} \mathrm{E}$ & Langford et al. (2010a) & T/C: $87 / 13$ & T/E: 78/15 \\
\hline Congo & Mixed tropical & 03/1996 & $2^{\circ} \mathrm{N}, 16^{\circ} \mathrm{E}$ & Serca et al. (2001) & T/C: 93/7 & $\mathrm{T} / 95$ \\
\hline Congo & Mixed tropical & $11 / 1996$ & $2^{\circ} \mathrm{N}, 16^{\circ} \mathrm{E}$ & Serca et al. (2001) & T/C: $93 / 7$ & $\mathrm{~T} / 95$ \\
\hline Congo & Mixed tropical & $11 / 1996$ & $4^{\circ} \mathrm{N}, 18^{\circ} \mathrm{E}$ & Greenberg et al. (1999) & T/Sv/C: 72/18/10 & T/Sv: 76/19 \\
\hline South Africa & Savanna & $02 / 2001$ & $25^{\circ} \mathrm{S}, 31^{\circ} \mathrm{E}$ & Harley et al. (2003) & $\mathrm{C} / \mathrm{Sh} / \mathrm{Sv}:$ 64/22/14 & C/D/T: $66 / 14 / 18$ \\
\hline Mongolia & Grassland & $06-07-08 / 2002$ & $44^{\circ} \mathrm{N}, 116^{\circ} \mathrm{E}$ & Bai et al. (2006) & C/Sh: 97/2 & G/C: $84 / 10$ \\
\hline Mongolia & Grassland & 09/2002 & $44^{\circ} \mathrm{N}, 116^{\circ} \mathrm{E}$ & Bai et al. (2006) & C/Sh: $97 / 2$ & G/C: $84 / 10$ \\
\hline SW China & Plantation & $02-03 / 2002$ & $21^{\circ} \mathrm{N}, 101^{\circ} \mathrm{E}$ & Baker et al. (2005) & $\mathrm{T}: 100$ & T/D/E: 43/27/27 \\
\hline SW China & Plantation & $07 / 2002$ & $21^{\circ} \mathrm{N}, 101^{\circ} \mathrm{E}$ & Baker et al. (2005) & $\mathrm{T}: 100$ & T/D/E: 43/27/27 \\
\hline Germany & Deciduous & 07/2001-2002 & $50^{\circ} \mathrm{N}, 11^{\circ} \mathrm{E}$ & Graus et al. (2006) & $\mathrm{C} / \mathrm{D}: 48 / 47$ & C/D: $84 / 15$ \\
\hline NW Germany & Deciduous & $07 / 2003$ & $50^{\circ} \mathrm{N}, 6^{\circ} \mathrm{E}$ & Spirig et al. (2005) & C/D: $52 / 48$ & C/D: $85 / 14$ \\
\hline Germany & Deciduous & 08/1995 & $50^{\circ} \mathrm{N}, 8^{\circ} \mathrm{E}$ & Steinbrecher et al. (2000) & D/C: $59 / 41$ & C/D: 74/24 \\
\hline Sweden & Plantation & $07 / 2001$ & $58^{\circ} \mathrm{N}, 12^{\circ} \mathrm{E}$ & Olofsson et al. (2005) & E/C/D: 49/35/16 & C: 97 \\
\hline Finland & Boreal & $08 / 2001$ & $61^{\circ} \mathrm{N}, 24^{\circ} \mathrm{E}$ & Spirig et al. (2004) & E/D/C: $35 / 33 / 32$ & E/C: $75 / 19$ \\
\hline $\mathrm{N}$ Wisconsin & Deciduous & $07 / 1993$ & $46^{\circ} \mathrm{N}, 90^{\circ} \mathrm{W}$ & Isebrands et al. (1999) & D/C/Sv: 43/37/19 & $\mathrm{C}: 86$ \\
\hline UMBS & Deciduous & 06-07-08/2000-2002 & $46^{\circ} \mathrm{N}, 85^{\circ} \mathrm{W}$ & Pressley et al. (2005) & D/E/C: 57/29/13 & E/D/C: $36 / 33 / 31$ \\
\hline UMBS & Deciduous & 08/1998 & $46 \mathrm{~N}, 85 \mathrm{~W}$ & Westberg et al. (2001) & D/E/C: 57/29/13 & E/D/C: $36 / 33 / 31$ \\
\hline Harvard Forest & Deciduous & 06-07-08/1995 & $45^{\circ} \mathrm{N}, 72^{\circ} \mathrm{W}$ & Goldstein et al. (1998) & D/C: $92 / 8$ & D/C: $64 / 26$ \\
\hline Canada & Boreal & $07 / 1994$ & $42^{\circ} \mathrm{N}, 72^{\circ} \mathrm{W}$ & Pattey et al. (1999) & $\mathrm{C} / \mathrm{E} / \mathrm{Sv}: 67 / 16 / 10$ & C/E: 70/13 \\
\hline Canada & Boreal & 09/1994 & $54^{\circ} \mathrm{N}, 105^{\circ} \mathrm{W}$ & Pattey et al. (1999) & $\mathrm{C} / \mathrm{E} / \mathrm{Sv}: 67 / 16 / 10$ & C/E: 70/13 \\
\hline London & Urban & $10 / 2006$ & $54^{\circ} \mathrm{N}, 105^{\circ} \mathrm{W}$ & Langford et al. (2010b) & $\mathrm{D} / \mathrm{C}: 57 / 43$ & C: 98 \\
\hline
\end{tabular}

\subsubsection{Global database of campaign-average isoprene flux measurements}

Our goal is to assess the model's ability to capture the isoprene emission variability across a wide range of ecosystem types and seasons. We have assembled a global database of campaign-average above-canopy isoprene flux measurements obtained between 1995-2010 (Table 4). The measurements are sorted by ecosystem type. The dominant vegetation fraction in the model grid cells for both the standard and $\mathrm{SiB} 2$ vegetation cover data sets corresponds to the local ecosystem at the measurement towers for all sites in the database except for South Africa and SW China. Table 5 compares the model simulated isoprene emission in SimCONT, SimH2O and SimSiB2 to the observations in the benchmark database (shown graphically in Fig. 6 for SimCONT and SimH2O results). The model results are monthly or seasonal averages that correspond to the time period during which the observations were made. The campaign periods are typically shorter than one month and as such the observations tend to refer to shorter averaging periods than in the model output. In some cases the published observational campaign-average is for mid-day average or daytime aver- age as indicated in Table 5. Evaluation against this global database suggests possible systematic biases in the model: under prediction in the summer time Canadian boreal but over prediction in the Scandinavian boreal. The model performs well in simulating the magnitude of isoprene mission in the tropical biome but appears to simulate either a lack of seasonality or reverse seasonality compared to that observed at the non-Amazon tropical rainforest sites. The ORCHIDEE model isoprene emission has been compared to a limited subset of this global database (Canada, UMBS and Santarem) (Lathiére et al., 2006). Similar to Yale-E2, ORCHIDEE reproduced the tropical flux magnitude well but underpredicted at the Canada and UMBS sites. The presence of water stress has the largest impact on the magnitude of isoprene emission rate in the North American deciduous sites. Based on linear regression, the control run SimCONT is able to reproduce $50 \%$ of the variability across different ecosystems and seasons in the global database. $\mathrm{SimH} 2 \mathrm{O}$ and $\mathrm{SimSiB} 2$ capture $64 \%$ and $40 \%$ of the variability in the global database, respectively. The model/measurement discrepancies in the isoprene emission magnitude are most likely due to the model's assignment of PFT-specific emission potentials (fraction of electrons available for isoprene synthesis, $\varepsilon$ ) that in reality 
Table 5. Comparison of the global database and simulated isoprene emission. Units are $\mathrm{mgC} \mathrm{m}^{-2} \mathrm{~h}^{-1}$. The model values are either monthly or seasonal means to be consistent with the observation time period. The averaging period for the observations is indicated where the information is available. [MDA = mid-day average; DTA = daytime average; $\mathrm{CA}=$ campaign average; $\mathrm{DTMX}=$ daytime maximum $]$.

\begin{tabular}{|c|c|c|c|c|}
\hline \multirow[t]{2}{*}{ Location } & \multirow[t]{2}{*}{ Measurement } & \multicolumn{3}{|c|}{ Model } \\
\hline & & SimCONT & $\mathrm{SimH} 2 \mathrm{O}$ & SimSiB2 \\
\hline Santarem & 1-2 MDA & $2.02 \pm 0.09$ & $1.85 \pm 0.07$ & $1.96 \pm 0.09$ \\
\hline Manaus & 2.1 DTA & $1.00 \pm 0.42$ & $1.98 \pm 0.09$ & $0.53 \pm 0.48$ \\
\hline Manaus & 7.8 MDA & $2.58 \pm 0.10$ & $2.51 \pm 0.09$ & $2.62 \pm 0.12$ \\
\hline Costa Rica & $1.35 \mathrm{MDA}$ & $2.09 \pm 0.22$ & $2.22 \pm 0.07$ & $1.30 \pm 0.32$ \\
\hline Costa Rica & 2.5 & $1.48 \pm 0.11$ & $1.67 \pm 0.12$ & $1.63 \pm 0.12$ \\
\hline Malaysia & $1.20 \mathrm{CA}$ & $1.62 \pm 0.08$ & $1.59 \pm 0.12$ & $1.22 \pm 0.05$ \\
\hline Borneo & $0.54 \mathrm{CA}$ & $2.23 \pm 0.08$ & $2.06 \pm 0.09$ & $1.99 \pm 0.10$ \\
\hline Borneo & $1.2 \mathrm{CA}$ & $1.42 \pm 0.26$ & $2.00 \pm 0.10$ & $1.05 \pm 0.31$ \\
\hline Congo & 1.4 MDA & $2.02 \pm 0.10$ & $1.89 \pm 0.09$ & $2.08 \pm 0.08$ \\
\hline Congo & $0.46 \mathrm{MDA}$ & $1.80 \pm 0.06$ & $1.93 \pm 0.13$ & $1.72 \pm 0.09$ \\
\hline Congo & $0.6-1.3$ & $1.33 \pm 0.14$ & $1.78 \pm 0.09$ & $1.70 \pm 0.12$ \\
\hline South Africa & $0.34 \mathrm{MDA}$ & $0.72 \pm 0.12$ & $0.92 \pm 0.08$ & $0.49 \pm 0.21$ \\
\hline Mongolia & 0.5 & $0.03 \pm 0.00$ & $0.04 \pm 0.00$ & $0.48 \pm 0.05$ \\
\hline Mongolia & 0.38 & $0.02 \pm 0.00$ & $0.02 \pm 0.00$ & $0.30 \pm 0.02$ \\
\hline SW China & 0.15 DTA & $0.12 \pm 0.08$ & $0.66 \pm 0.11$ & $0.06 \pm 0.15$ \\
\hline SW China & 1 DTA & $0.24 \pm 0.54$ & $1.64 \pm 0.16$ & $0.34 \pm 0.39$ \\
\hline Germany & $0.21-0.33$ DTMX & $1.37 \pm 0.33$ & $1.52 \pm 0.15$ & $0.49 \pm 0.12$ \\
\hline NW Germany & $3.4 \mathrm{CA}$ & $1.36 \pm 0.12$ & $1.68 \pm 0.15$ & $0.48 \pm 0.05$ \\
\hline Germany & $0.8 \mathrm{CA}$ & $0.95 \pm 0.26$ & $1.34 \pm 0.17$ & $0.12 \pm 0.08$ \\
\hline Sweden & $0.44 \mathrm{CA}$ & $1.79 \pm 0.11$ & $2.26 \pm 0.19$ & $0.43 \pm 0.04$ \\
\hline Finland & $0.035 \mathrm{CA}$ & $0.78 \pm 0.10$ & $0.97 \pm 0.08$ & $0.40 \pm 0.08$ \\
\hline N. Wisconsin & 1-1.89 DTA & $1.75 \pm 0.50$ & $2.20 \pm 0.15$ & $0.35 \pm 0.08$ \\
\hline UMBS, US & 3 MDA & $0.35 \pm 0.11$ & $2.56 \pm 0.14$ & $0.21 \pm 0.05$ \\
\hline UMBS, US & $\begin{array}{l}9-10 \text { (warm period }) \\
0.9-1.8 \text { (cool period })\end{array}$ & $0.40 \pm 0.13$ & $2.35 \pm 0.18$ & $0.24 \pm 0.06$ \\
\hline Harvard & 1.16 DTA & $0.79 \pm 0.14$ & $3.40 \pm 0.14$ & $0.66 \pm 0.24$ \\
\hline Canada & 2.29 & $0.27 \pm 0.09$ & $0.31 \pm 0.01$ & $0.40 \pm 0.10$ \\
\hline Canada & 0.54 & $0.13 \pm 0.03$ & $0.12 \pm 0.02$ & $0.16 \pm 0.02$ \\
\hline London & $0.13 \mathrm{CA}$ & $0.35 \pm 0.05$ & $0.42 \pm 0.05$ & $0.01 \pm 0.00$ \\
\hline
\end{tabular}

vary greatly for a single plant species (Goldstein et al., 1998) and across plant species lumped into each PFT class e.g. (Rinne et al., 2009). For example, the deciduous PFT includes species that are strong isoprene emitters (willows, aspen) and others that do not emit isoprene (birches).

\subsubsection{Time-varying isoprene emission through campaign periods}

We examine the time-varying performance at 9 select measurement sites described in Table 6. Some of the sites are part of the global database of campaign-average fluxes (Table 3). There are 4 tropical sites on 2 different continents, 4 temperate broadleaf sites on 2 different continents, and 1 temperate mixed site in Europe. At 3 of the temperate sites, measurements are available across multiple years: Harvard Forest (1995 and 2007); UMBS (2000, 2001, 2002, 2003, 2005); and Belgium (2009-2011). These three sites provide measurements that span an entire growing season. The remaining 6 sites offer measurements over periods of a few days to several weeks. The sites in southern France (La Verdière and Montmeyan) occur in the same model grid cell. We focus on analysis of the control run SimCONT and the sensitivity simulation SimH2O. Sub-daily model output is generated at half-hourly resolution (the physical time step of the climate model itself). The model isoprene emissions are $10 \mathrm{yr}$ climatological averages for present-day, thus cannot be expected to reproduce the day-to-day weather-related variability in the observations.

In this section, we assess qualitatively the model/measurement comparison of isoprene emission, surface air temperature (SAT) and downward shortwave radiation (SW) across the entire campaign period for the 6 sites with measurement periods shorter than a growing season. The goal is to identify possible model biases in isoprene emission magnitude before a more quantitative assessment of the average diurnal cycle is executed in the next section. Results for tropical sites are shown in Fig. 7a-f and results for the temperate sites are shown in 

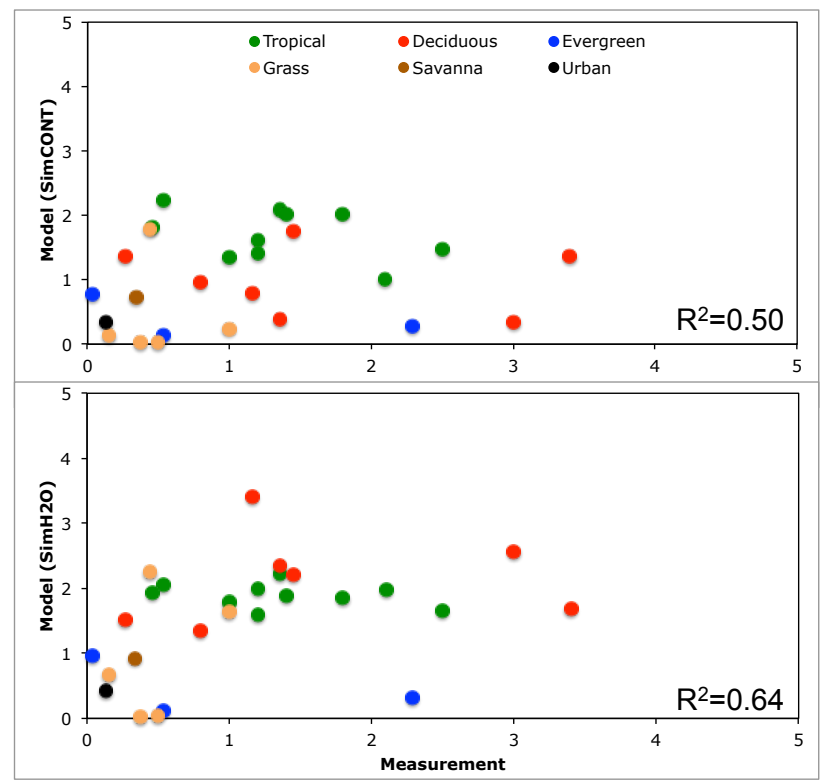

Fig. 6. Scatter plot of the simulated isoprene emissions against measurements from the global above-canopy flux database sorted by ecosystem type (Table 5). "Plantation" measurements are lumped into "crop" here. Units are $\mathrm{mgC} \mathrm{m}^{-2} \mathrm{~h}^{-1}$. Values and temporal averaging periods are detailed in Table 5.

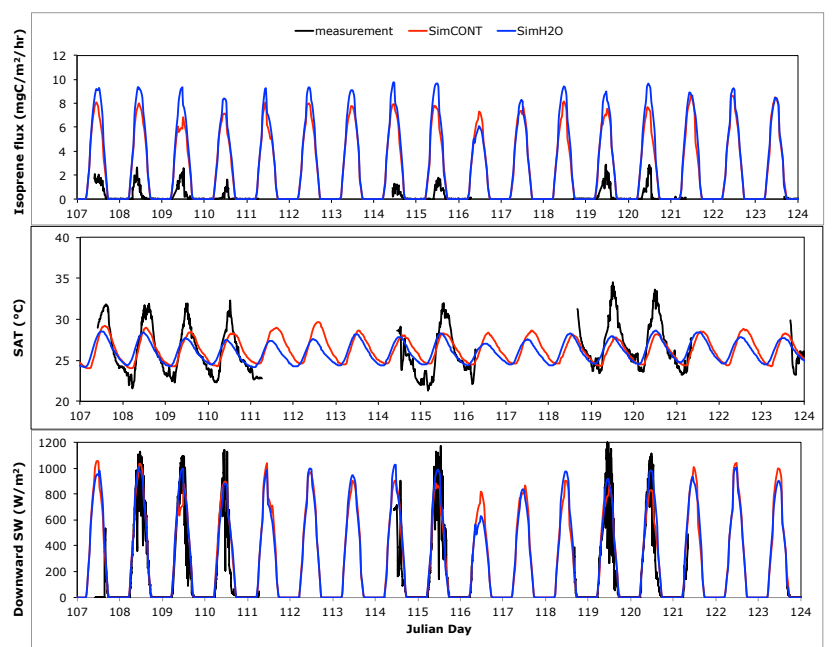

Fig. 7a. (a-f) Time evolution of isoprene emission flux, surface air temperature (SAT) and downward shortwave (SW) radiation at the tropical measurement sites. Measurements are shown in black (where data is available). Model climatological results are averages of 10 simulation years in SimCONT (red) and SimH2O (blue). (a) Costa Rica during 17 April-4 May, 2003.

Fig. 8a-e. Results for Harvard Forest (2007) have been split into three separate time periods. Meteorological data are not available for all sites. Measured isoprene fluxes are highly variable during the day at both tropical and temperate sites reflecting the local weather conditions. The model

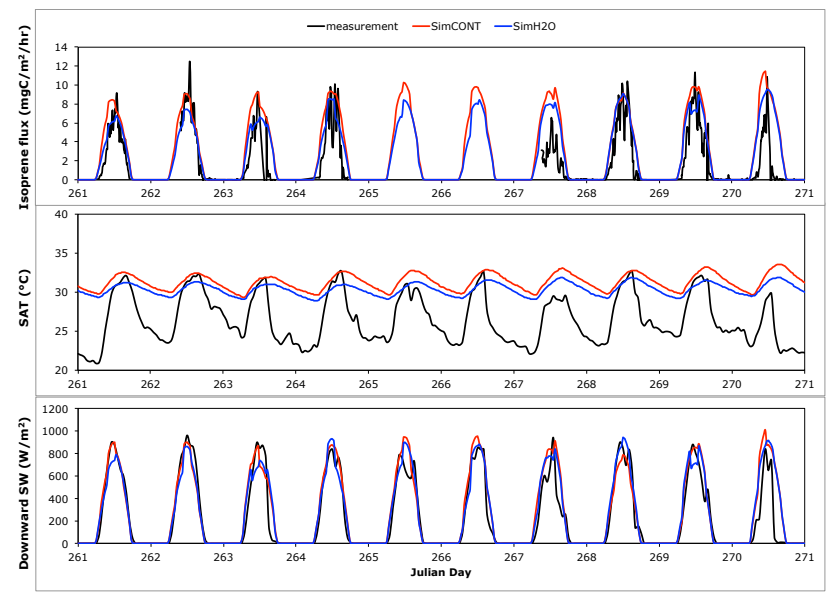

Fig. 7b. (a-f) Time evolution of isoprene emission flux, surface air temperature (SAT) and downward shortwave (SW) radiation at the tropical measurement sites. Measurements are shown in black (where data is available). Model climatological results are averages of 10 simulation years in SimCONT (red) and SimH2O (blue). (b) Manaus during 17-27 September 2004.

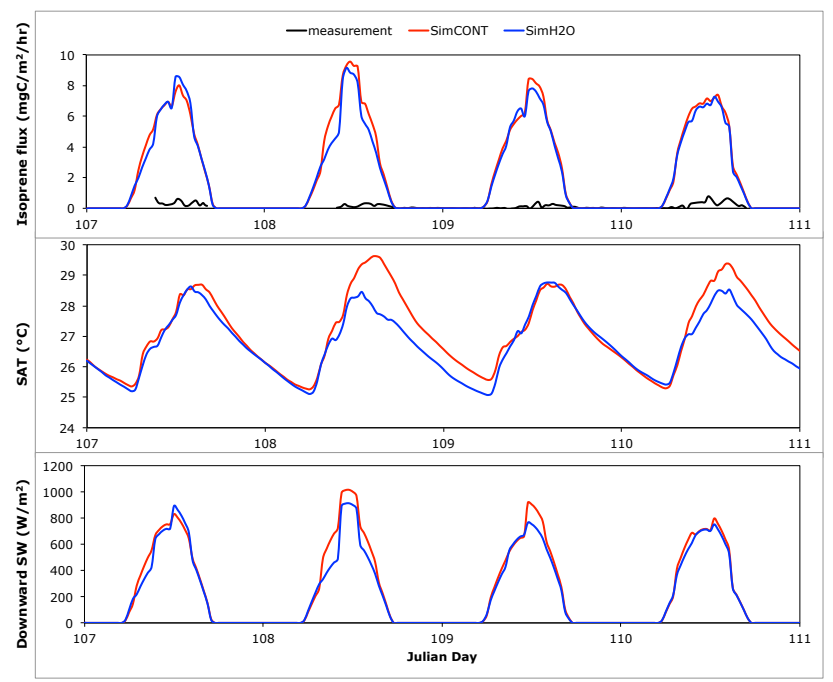

Fig. 7c. (a-f) Time evolution of isoprene emission flux, surface air temperature (SAT) and downward shortwave (SW) radiation at the tropical measurement sites. Measurements are shown in black (where data is available). Model climatological results are averages of 10 simulation years in SimCONT (red) and SimH2O (blue). (c) wet season Santarem during 17-21 April 2001.

reproduces the SW with striking fidelity at both the tropical sites and temperate sites (where data is available). The SAT simulation is generally weaker and the discrepancies are not related to a particular biome. In Costa Rica, the model underestimates the diurnal range in temperature. In Manaus, La Verdière and Montmeyan, the model captures accurately the daytime maximum SAT but is not able to simulate the nighttime minimum (the nighttime SAT is too warm in the 

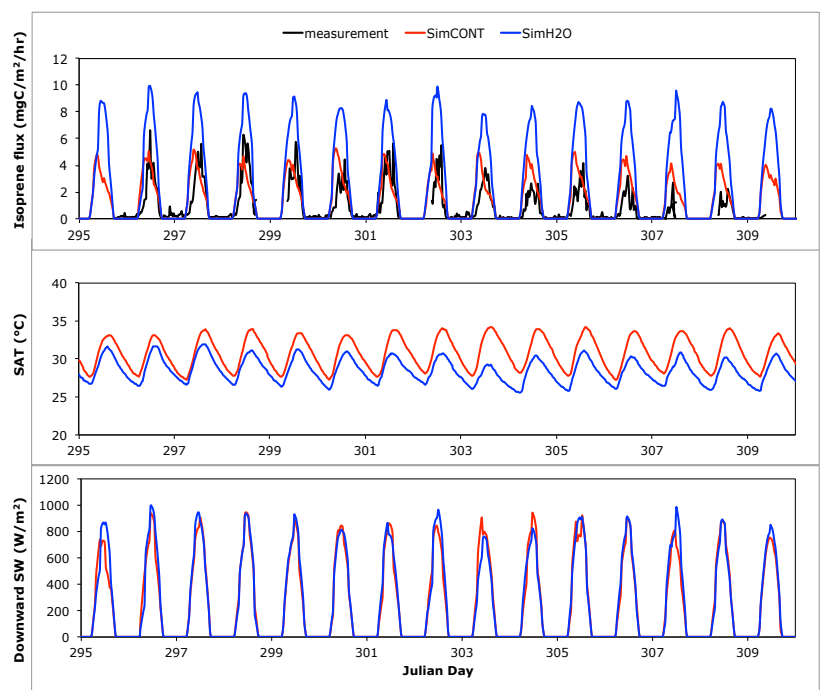

Fig. 7d. (a-f) Time evolution of isoprene emission flux, surface air temperature (SAT) and downward shortwave (SW) radiation at the tropical measurement sites. Measurements are shown in black (where data is available). Model climatological results are averages of 10 simulation years in SimCONT (red) and SimH2O (blue). (d) dry season Santarem during 22 October-6 November 2003.
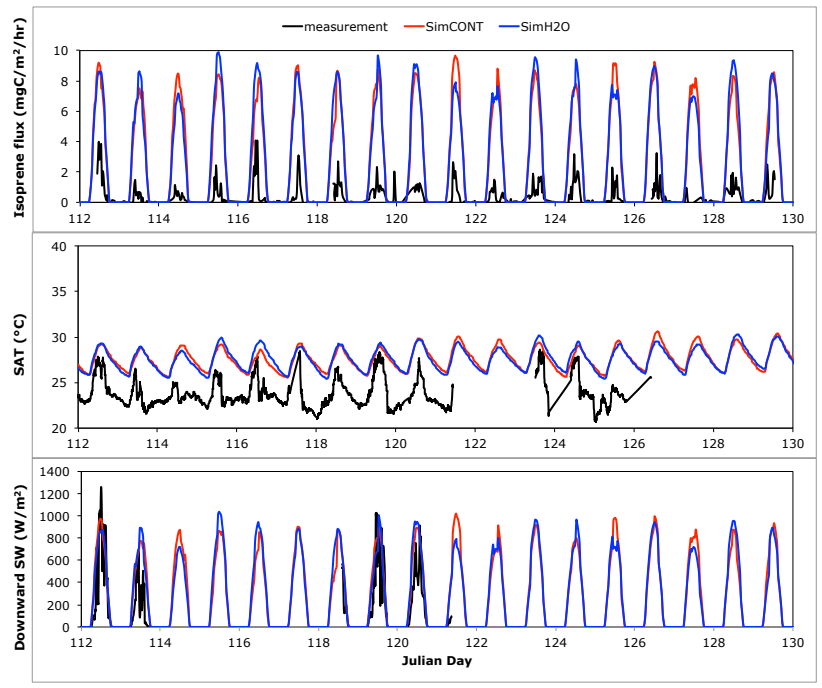

Fig. 7e. (a-f) Time evolution of isoprene emission flux, surface air temperature (SAT) and downward shortwave (SW) radiation at the tropical measurement sites. Measurements are shown in black (where data is available). Model climatological results are averages of 10 simulation years in SimCONT (red) and SimH2O (blue). (e) wet season Borneo during 21 April-9 May 2008.

model versus the observations). In Borneo the model's SAT diurnal range appears reasonable but there is a consistent $\sim 5^{\circ} \mathrm{C}$ positive bias. Only at the Harvard Forest site does the model accurately reproduce the observed SAT throughout the measurement campaign. It must be emphasized that the

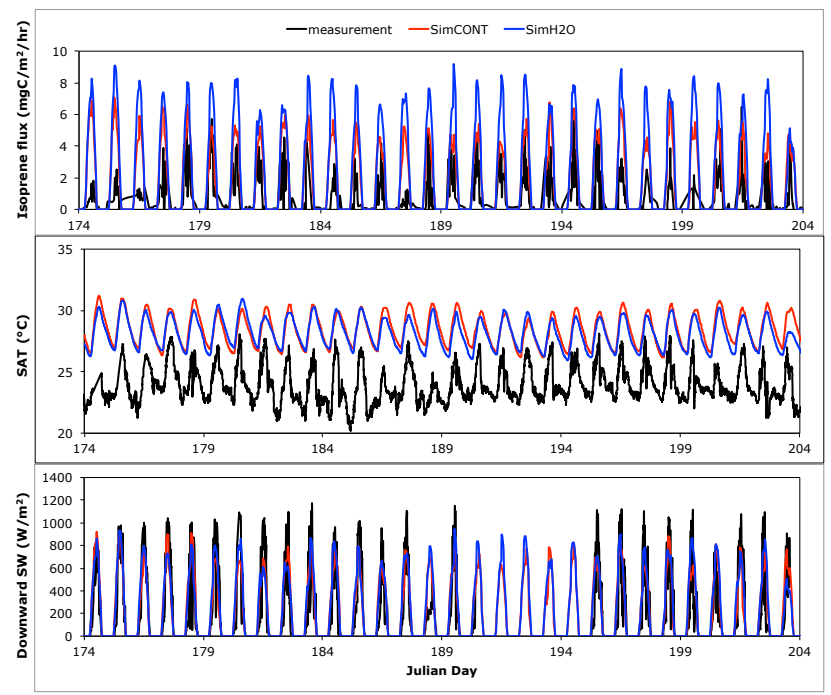

Fig. 7f. (a-f) Time evolution of isoprene emission flux, surface air temperature (SAT) and downward shortwave (SW) radiation at the tropical measurement sites. Measurements are shown in black (where data is available). Model climatological results are averages of 10 simulation years in SimCONT (red) and SimH2O (blue).(f) early dry season Borneo during 22 June-22 July 2008.

model's climatological temperature and radiation variables refer to average values over the $2^{\circ} \times 2.5^{\circ}$ grid cell. SAT is expected to exhibit much higher sub-grid scale variability than downward SW.

The model demonstrates significant skill in closely reproducing the time-varying isoprene emission in the dry season tropics at the Manaus, Santarem and Borneo (early-dry) sites. However, there is an obvious model overestimate at the Costa Rica, Santarem and Borneo sites in the wet season. A large part of the discrepancy is likely related to variation in the emission potential $(\varepsilon)$ across different tropical forests. Some of the discrepancy at the Santarem site in the wet season may be related to the lack of leaf age effects in the model (i.e. no seasonal variation in $\varepsilon$ ). For instance, low HCHO columns over Amazonia observed from space during the wet season have been ascribed to leaf flushing prior to the dry season (Barkley et al., 2009).

As expected, at the wet season tropical sites, SimCONT and $\mathrm{SimH} 2 \mathrm{O}$ yield similar climatological fluxes. At the dry season tropical sites, especially Santarem and Borneo, SimCONT reduces to about half the value in $\mathrm{SimH} 2 \mathrm{O}$ and more closely matches the observations lending some confidence in the model's simulation of water-stressed photosynthesis and isoprene emission in this region, previously indicated in Fig. 5a. Some of the model overestimate in Borneo may be related to the climate model's high bias in SAT. At the temperate sites in the growing season, the isoprene emission magnitude is well captured in the model (within a factor of 2 of the observations). At Montmeyan (June) both model 


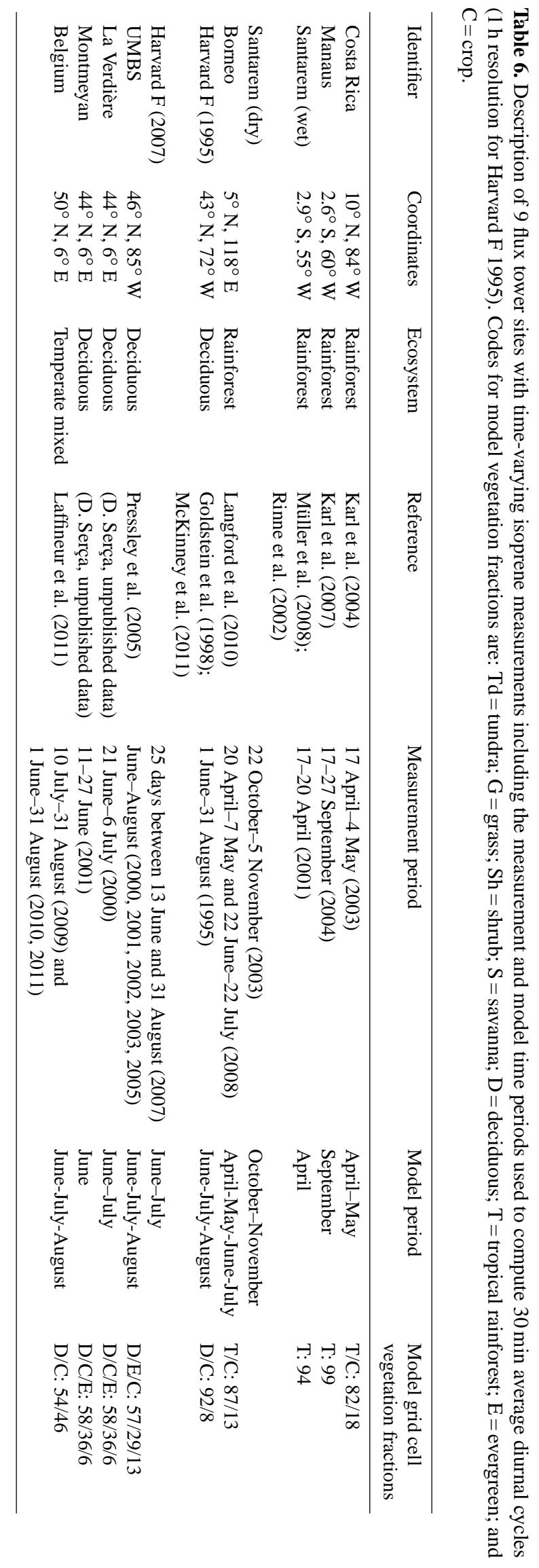




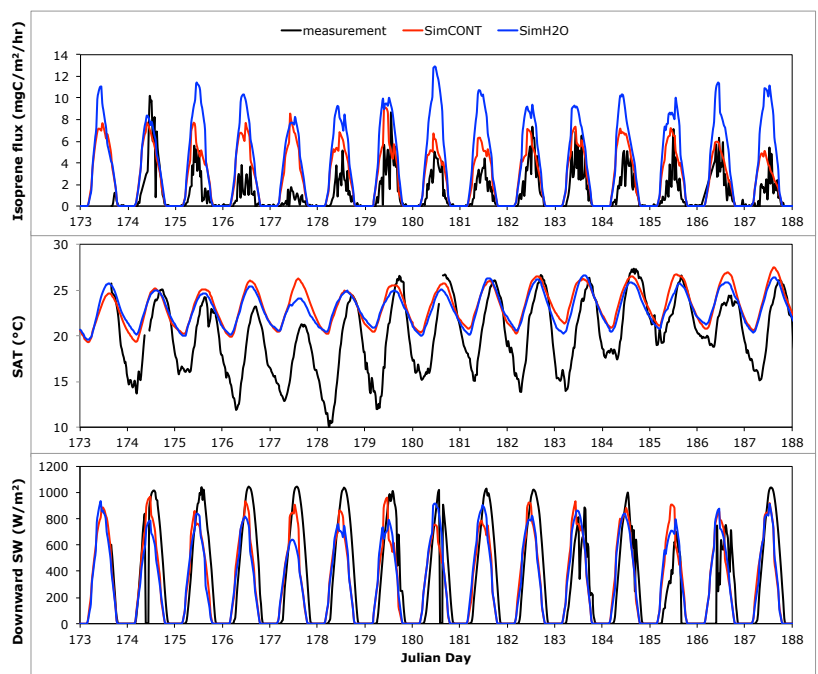

Fig. 8a. (a-e) Time evolution of isoprene emission flux, surface air temperature (SAT) and downward shortwave (SW) radiation at the temperate measurement sites. Measurements are shown in black (where data is available). Model climatological results are averages of 10 simulation years in SIMCONT (red) and SimH2O (blue). (a) La Verdière during 21 June-6 July 2000.

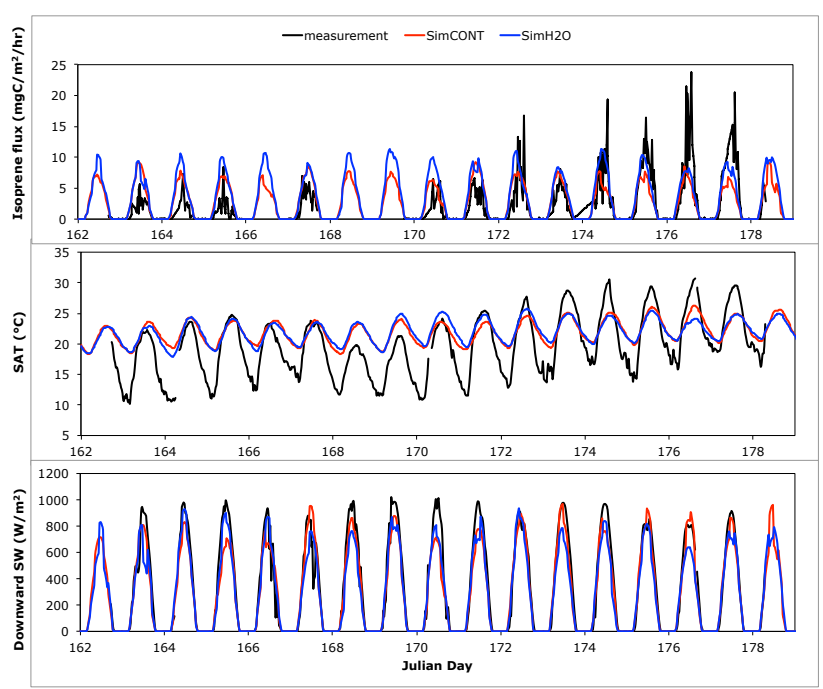

Fig. 8b. (a-e) Time evolution of isoprene emission flux, surface air temperature (SAT) and downward shortwave (SW) radiation at the temperate measurement sites. Measurements are shown in black (where data is available). Model climatological results are averages of 10 simulation years in SIMCONT (red) and SimH2O (blue). (b) Montmeyan during 11-27 June 2001.

runs perform well, whereas at La Verdière (June-July), SimCONT reproduces the measured isoprene flux more closely than $\mathrm{SimH} 2 \mathrm{O}$, indicative of increases in water stress later into the growing season. At the Harvard Forest site, the measured fluxes tend to lie between SimCONT and SimH2O.

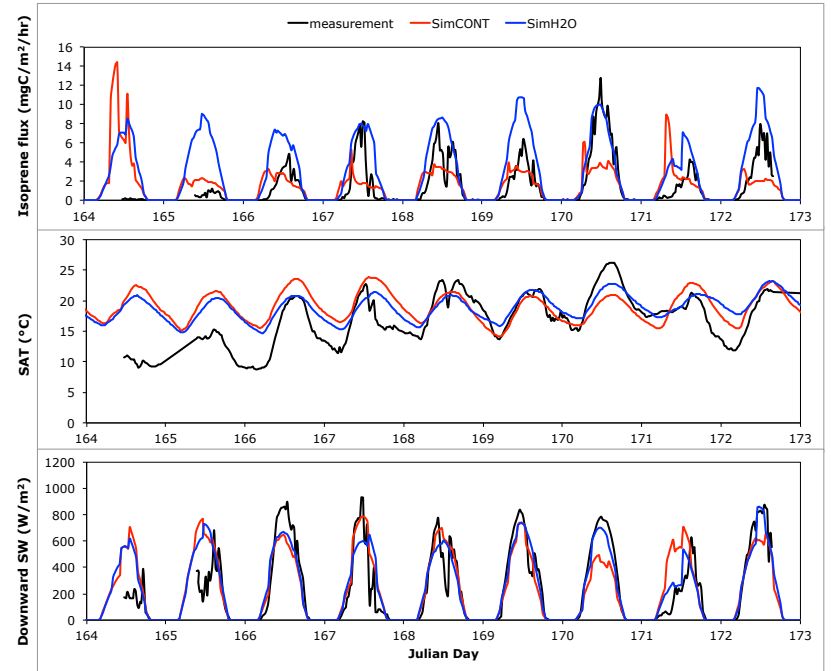

Fig. 8c. (a-e) Time evolution of isoprene emission flux, surface air temperature (SAT) and downward shortwave (SW) radiation at the temperate measurement sites. Measurements are shown in black (where data is available). Model climatological results are averages of 10 simulation years in SIMCONT (red) and SimH2O (blue). (c) Harvard Forest during 13-22 June 2007.

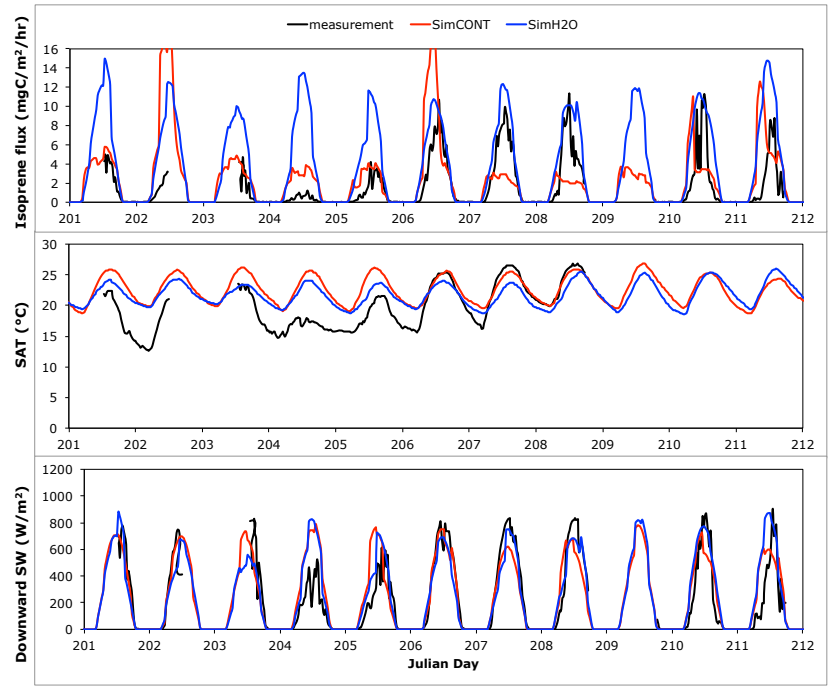

Fig. 8d. (a-e) Time evolution of isoprene emission flux, surface air temperature (SAT) and downward shortwave (SW) radiation at the temperate measurement sites. Measurements are shown in black (where data is available). Model climatological results are averages of 10 simulation years in SIMCONT (red) and SimH2O (blue). (d) Harvard Forest during 20-31 July 2007.

The model reproduces the decrease in emission magnitude in early September at this site. 

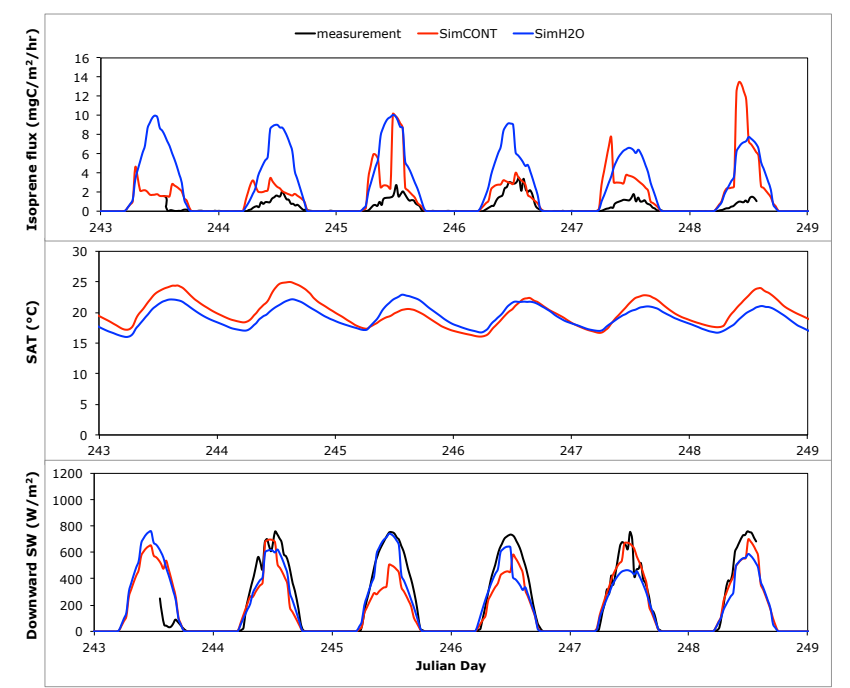

Fig. 8e. (a-e) Time evolution of isoprene emission flux, surface air temperature (SAT) and downward shortwave (SW) radiation at the temperate measurement sites. Measurements are shown in black (where data is available). Model climatological results are averages of 10 simulation years in SIMCONT (red) and SimH2O (blue). (e) Harvard Forest during 31 August-6 September 2007.

\subsubsection{Isoprene and GPP diurnal cycle}

We constructed campaign average diurnal cycles at $30 \mathrm{~min}$ resolution for isoprene emission at the 9 measurement sites ( $1 \mathrm{~h}$ resolution for Harvard Forest in 1995) and GPP at 2 temperate sites where suitable data is available (UMBS and Harvard Forest). The measurement days included in the averaging are indicated in Table 6. At UMBS and Belgium, the isoprene (and GPP at UMBS) average diurnal cycle includes the data for all available years. The interannual variability in the measured isoprene diurnal cycle $(30-100 \%)$ is larger than for the GPP diurnal cycle $(<5 \%)$ (not shown).

Comparison between measured and modeled isoprene average diurnal cycles at the tropical and temperate sites are shown in Fig. 9a and b, and GPP average diurnal cycle at 2 temperate sites in Fig. 9c. Model/measurement evaluation statistics including the correlation coefficient for linear regression and root mean square error (RMSE) are indicated in Tables 7 and 8 along with a comparison of the measured and modeled maximum average diurnal emission. The measured diurnal average profiles show large fluctuations during the middle of the day that are not seen in the smoother 10year average model climatologies. The $5 \mathrm{yr}$ average diurnal average at UMBS does not exhibit fluctuations to the same extent as the other sites.

The model simulates the magnitude of the average diurnal cycle in the dry season tropics and the growing season temperate zone (except at Belgium) to within a factor of 2, which is comparable to the performance of higher spatial resolution models driven with observed meteorology that are used in air

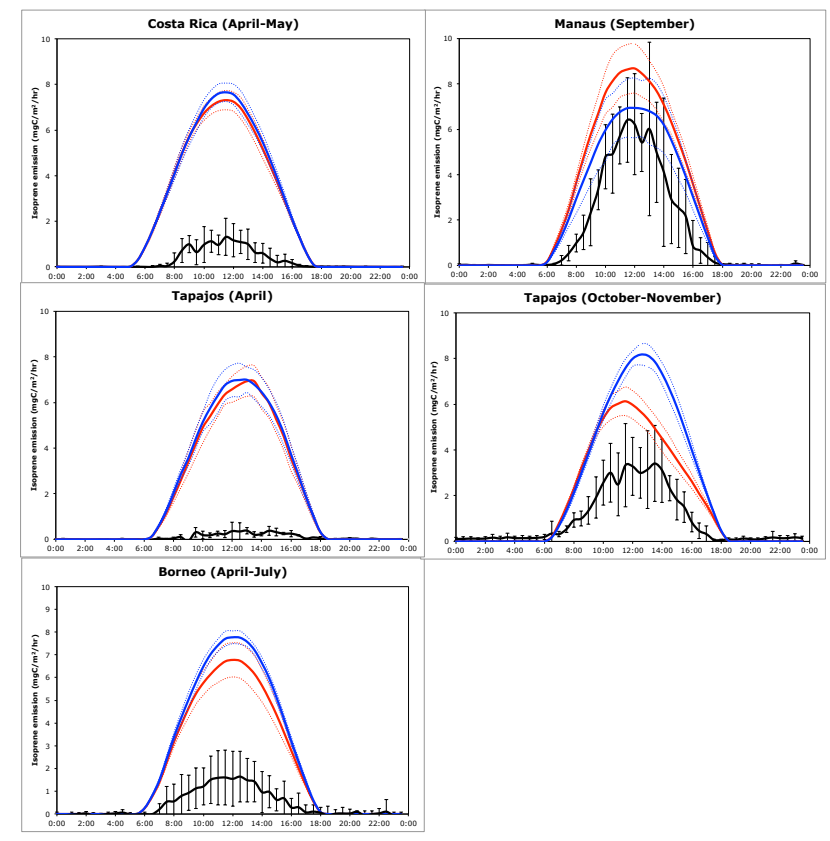

Fig. 9a. (a-c) Comparison between measured and modeled isoprene emission and GPP average diurnal cycles for the time periods indicated in Table 6. Measurements are black lines. Error bars on the measurements represent \pm 1 standard deviation. Model results are $10 \mathrm{yr}$ climatological averages for SimCONT (red) and SimH2O (blue). The dotted lines represent model uncertainty due to internal variability in the climate model computed as \pm 1 standard deviation for $n=10$ model run years. (a) isoprene emission tropical sites (wet season results are shown in the left column and dry season results are shown in the right column)

quality modeling for the development of environmental policy e.g. (Warneke et al., 2010; Arneth et al., 2011). Based on the RMSE (Table 7), the control run SimCONT performs better than $\mathrm{SimH} 2 \mathrm{O}$ in simulating the emission magnitude, especially at UMBS, Harvard Forest and the seasonally dry tropics. The large model/measurement discrepancy ( f factor of 5) at Belgium is because the model classifies the grid cell as deciduous PFT whereas in reality the measurement site is mixed temperate composed of coniferous (Douglas fir) and deciduous (beech). The fraction of electrons available for isoprene synthesis $(\varepsilon)$ is a factor of 4 higher for the deciduous PFT than the evergreen PFT (Table 1). In reality, the contribution to the isoprene flux at the Belgium site from coniferous versus deciduous is small but beech is non-emitting for isoprene. We retain the Belgium site in this study because it illustrates the dependency of the model's simulation on the vegetation data set and structure (Schurgers et al., 2011; Arneth et al., 2011).

The simulated isoprene average diurnal cycle is lower at all sites (except Manaus) in SimCONT than SimH2O following the expected GPP response to the presence of water stress. In dry season Manaus, isoprene emission is higher in the 


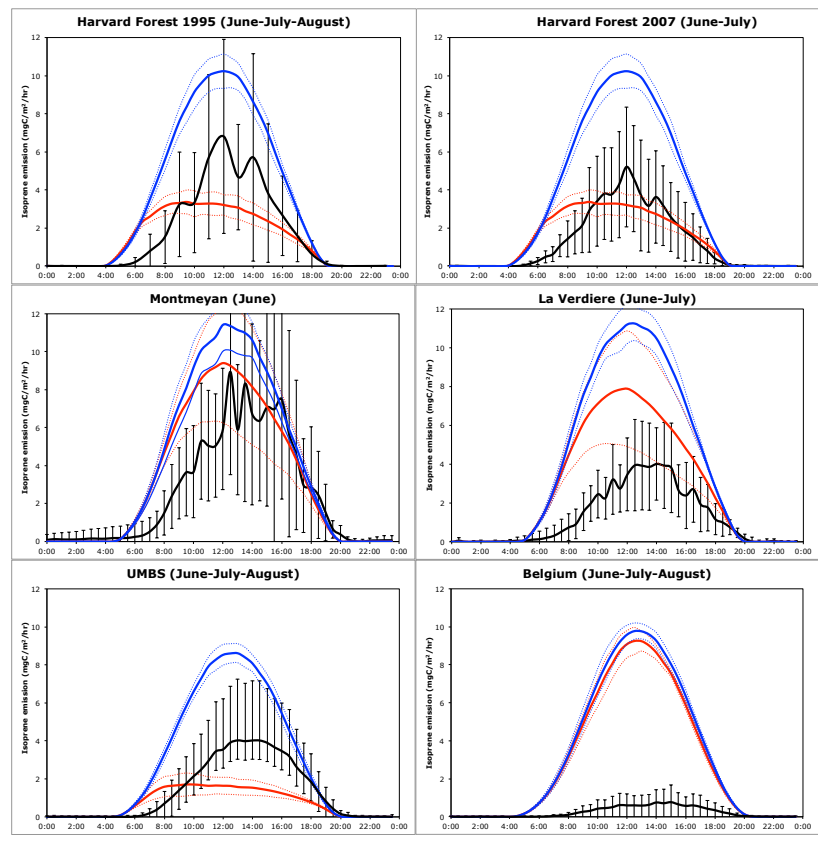

Fig. 9b. (a-c) Comparison between measured and modeled isoprene emission and GPP average diurnal cycles for the time periods indicated in Table 6. Measurements are black lines. Error bars on the measurements represent \pm 1 standard deviation. Model results are $10 \mathrm{yr}$ climatological averages for SimCONT (red) and SimH2O (blue). The dotted lines represent model uncertainty due to internal variability in the climate model computed as \pm 1 standard deviation for $n=10$ model run years. (b) isoprene mission temperate sites.

water-stressed control run because drought-induced stomatal closure drives higher canopy temperatures that stimulate the isoprene emission. At the North American sites (Harvard Forest and UMBS), the isoprene emission rate is a factor of 3 lower in SimCONT than SimH2O. At these sites, the measured average diurnal cycle lies between the SimCONT and $\mathrm{SimH} 2 \mathrm{O}$ climatologies. Interestingly, $\mathrm{SimH} 2 \mathrm{O}$ authentically reproduces the GPP average diurnal cycle (Fig. 8c) at both sites (RMSE $\sim 0.1 \mathrm{gC} \mathrm{m}^{-2} \mathrm{~h}^{-1}, R^{2}>0.94$ ). SimCONT GPP average diurnal cycle is too low by a factor of $2-3$. It may be tempting to conclude that the water stress function in the control run is too strong at these locations, either because of errors in the climate model's soil moisture simulation (too dry), and/or because of the model's assignment of PFTspecific stress onset and wilting points. Discrepancies in the model's PFT-specific photosynthesis and isoprene emission parameters provide another possible explanation. For example, using a local emission potential $\left(I_{\mathrm{s}}\right)$ of $100 \mu \mathrm{gC} \mathrm{g} \mathrm{g}^{-1} \mathrm{~h}^{-1}$ for the deciduous PFT, more than double the generic value applied in Yale-E2 (Table 1), isoprene emission simulated in LPJ-GUESS is within 5-10\% of measured values at the UMBS site but only about half the magnitude of the measured values at the Harvard Forest 1995 site (Arneth et al., 2007). Increasing $I_{\mathrm{S}}$ to $160 \mu \mathrm{gC} \mathrm{g} \mathrm{g}^{-1} \mathrm{~h}^{-1}$ for the Harvard For-

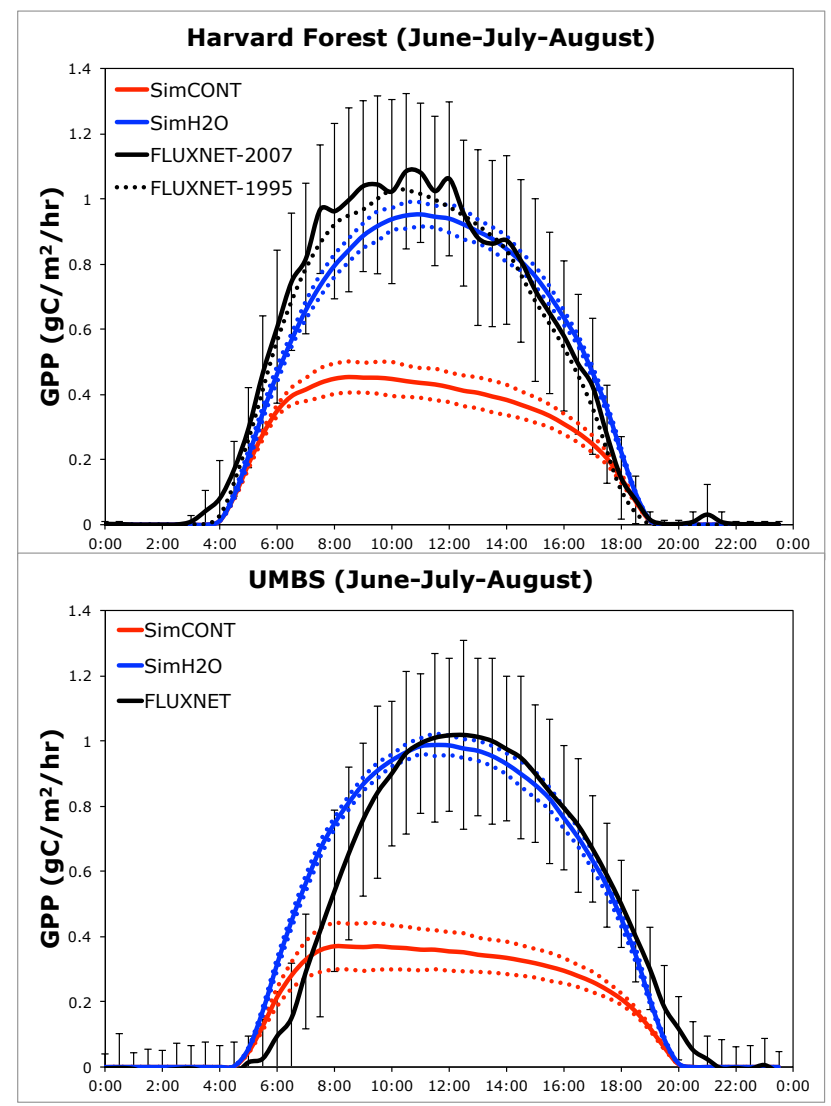

Fig. 9c. (a-c) Comparison between measured and modeled isoprene emission and GPP average diurnal cycles for the time periods indicated in Table 6. Measurements are black lines. Error bars on the measurements represent \pm 1 standard deviation. Model results are $10 \mathrm{yr}$ climatological averages for SimCONT (red) and SimH2O (blue). The dotted lines represent model uncertainty due to internal variability in the climate model computed as \pm 1 standard deviation for $n=10$ model run years. (c) GPP temperate sites.

est site in LPJ-GUESS improved the agreement with observations to within $20 \%$. In contrast, the JULES model used identical $I_{\mathrm{S}}$ values for temperate broadleaf $\left(45 \mu \mathrm{gC} \mathrm{g} \mathrm{g}^{-1} \mathrm{~h}^{-1}\right)$ and tropical $\left(24 \mu \mathrm{gC} \mathrm{g}^{-1} \mathrm{~h}^{-1}\right)$ as those applied in this study, but overestimated the isoprene emission flux at 6 of the 9 sites (UMBS, Harvard Forest, LV, Montmeyan, Manaus and Santarem) with the maximum discrepancy at La Verdiere $(+236 \%)$. In JULES, model isoprene emissions in the middle of the day and in the afternoons are generally higher than observed at all test sites.

Figure $9 \mathrm{a}$ and $\mathrm{b}$ suggest that the model isoprene emission ramps up too quickly in the morning hours compared to measurements at both tropical and temperate sites. The observed rate of emission decrease in the early evening is better captured by the model. The existence of a circadian rhythm in the PFT-specific fraction of electrons available for isoprene synthesis $(\varepsilon)$ provides one possible explanation, such that $\varepsilon$ is lower in the morning hours during the first onset of 
Table 7. Statistical performance of model simulated isoprene average diurnal cycles at 9 sites in the tropical and temperate zones.

\begin{tabular}{llllllll}
\hline Site & \multicolumn{2}{c}{$\begin{array}{c}\text { Linear regression coefficient } \\
\text { for 30 min data }\end{array}$} & \multicolumn{2}{l}{ RMSE $\left(\mathrm{mgC} \mathrm{m}^{-2} \mathrm{~h}^{-1}\right)$} & \multicolumn{3}{c}{ Maximum in average diurnal cycle } \\
& SimCONT & SimH2O & SimCONT & SimH2O & Measurement & SimCONT & SimH2O \\
\hline Costa Rica & 0.89 & 0.90 & 3.03 & 3.14 & 1.32 & 7.31 & 7.65 \\
Manaus & 0.93 & 0.93 & 1.78 & 1.11 & 6.41 & 8.68 & 6.94 \\
Santarem (wet) & 0.82 & 0.81 & 3.09 & 3.20 & 0.38 & 6.93 & 7.00 \\
Santarem (dry) & 0.92 & 0.95 & 1.44 & 2.32 & 3.41 & 6.13 & 8.17 \\
Borneo/OP3 & 0.96 & 0.96 & 2.57 & 3.04 & 1.65 & 6.78 & 7.77 \\
Harvard Forest (1995) & 0.67 & 0.90 & 1.33 & 2.62 & 7.40 & 3.37 & 10.23 \\
Harvard Forest (2007) & 0.74 & 0.95 & 0.81 & 3.23 & 5.21 & 3.37 & 10.23 \\
UMBS (5yrs) & 0.64 & 0.89 & 1.21 & 2.44 & 4.07 & 4.71 & 8.61 \\
La Verdière & 0.82 & 0.90 & 2.43 & 4.01 & 4.01 & 7.89 & 11.24 \\
Montmeyan & 0.81 & 0.84 & 1.78 & 2.48 & 8.95 & 9.40 & 11.41 \\
Belgium (3 yr) & 0.87 & 0.88 & 4.22 & 4.52 & 0.77 & 9.25 & 9.77 \\
\hline
\end{tabular}

Table 8. Statistical performance of model simulated GPP average diurnal cycles at 2 temperate sites.

\begin{tabular}{|c|c|c|c|c|c|c|c|}
\hline \multirow[t]{2}{*}{ Site } & \multicolumn{2}{|c|}{$\begin{array}{l}\text { Linear regression coefficient } \\
\text { for } 30 \mathrm{~min} \text { data }\end{array}$} & \multicolumn{2}{|c|}{$\operatorname{RMSE}\left(\mathrm{gC} \mathrm{m}^{-2} \mathrm{~h}^{-1}\right)$} & \multicolumn{3}{|c|}{ Maximum in average diurnal cycle } \\
\hline & SimCONT & $\mathrm{SimH} 2 \mathrm{O}$ & SimCONT & $\mathrm{SimH} 2 \mathrm{O}$ & Measurement & SimCONT & $\mathrm{SimH} 2 \mathrm{O}$ \\
\hline Harvard Forest (2007) & 0.97 & 0.97 & 0.34 & 0.09 & 1.08 & 0.45 & 0.95 \\
\hline UMBS (5yrs) & 0.79 & 0.94 & 0.36 & 0.10 & 1.02 & 0.37 & 0.99 \\
\hline
\end{tabular}

photosynthesis (Hewitt et al., 2011). We will explore the use of a diurnally varying $\varepsilon$ in future site-level work.

Based on linear regression (Table 7), the model demonstrates significant skill in capturing the observed variability in the $30 \mathrm{~min}$ average diurnal cycle across all sites (64-96\%). The model performance is best in the tropics $(>80 \%)$ where there is little difference between SimCONT and SimH2O. In the temperate zone, SimH2O demonstrates superior performance over SIMCONT (e.g. > 90\% versus 70-80\%) in reproducing the diurnal average variability, especially at Harvard Forest and UMBS. Essentially, the model is able to reproduce all of the observed variability in the average diurnal cycle at Santarem (dry), Manaus and Borneo. SimH2O reproduces the diurnal variability better than SimCONT at Harvard Forest (2007) and UMBS (all years). Despite the model's overestimate of emission magnitude at Belgium (because model PFT is deciduous in this location versus mixed temperate at the actual site), the model captures $>87 \%$ of the measured variability in average diurnal cycle.

\section{Discussion and conclusions}

Isoprene emission is a quintessential quantity in chemistryclimate interactions. In this study, we have implemented a biologically realistic photosynthesis-dependent isoprene emission scheme into a global chemistry-climate model framework. The model provides a new tool that will allow us to im- prove understanding of the multiple interactions between atmospheric chemistry, land ecosystem physiology and climate at regional and global scales that manifest through BVOC emissions. Such improvements are essential to provide adequate assessment of the climate and air quality benefits of mitigation strategies involving the short-lived climate forcers (Arneth et al., 2009).

Overall, based on comparison with above canopy flux measurements, the model provides an authentic representation of isoprene emission diurnal variability in tropical and temperate ecosystems but is less successful in reproducing the magnitude due to the assignment of PFT-specific isoprene emission potentials, and possibly biases in the climate model's internal meteorology. Current generation global climate models are limited to 5-20 PFTs. To improve simulation of isoprene emission magnitude in global models, more measurements of the plant-to-plant species level variability in isoprene emission (the isoprene emission potential) are needed as well as a way to represent the greater species diversity in models. In addition to accounting for leaf age effects, improvements in simulating isoprene variability may be achieved by including climate-sensitive phenology, variable atmospheric surface $\mathrm{CO}_{2}$ concentrations and the effects of ozone on plant physiology.

In future work, we will use the model to assess the impacts of the photosynthesis-dependent isoprene emission on atmospheric chemical composition and the impacts of global change on the isoprene emission. We will explore the 
Table A1. PFT-specific photosynthesis parameters used in Yale-E2 global carbon-chemistry-climate model.

\begin{tabular}{llllll}
\hline PFT & $\begin{array}{l}V_{\text {cmax }} \\
\left.(\mu \mathrm{mol} \mathrm{m})^{-2} \mathrm{~s}^{-1}\right)\end{array}$ & $\begin{array}{l}\text { Nleaf } \\
\left(\mathrm{g}[\mathrm{N}] \mathrm{m}^{-2}[\text { leaf }]\right)\end{array}$ & $\mathrm{s}^{*}$ & $\mathrm{~s}_{\text {wilt }}$ & $\begin{array}{l}\text { SLA } \\
\left(\mathrm{m}^{2}[\text { leaf }] \mathrm{kg}^{-1}[\text { leaf }]\right)\end{array}$ \\
\hline Tundra & 21 & 1.60 & 0.50 & 0.30 & 2.25 \\
Grass & 26 & 3.27 & 0.30 & 0.10 & 11.7 \\
Shrub & 17 & 2.38 & 0.40 & 0.22 & 3.25 \\
Savanna & 30 & 3.12 & 0.65 & 0.22 & 5.1 \\
Deciduous & 30 & 1.07 & 0.50 & 0.29 & 8.3 \\
Evergreen & 42 & 1.80 & 0.50 & 0.25 & 5.9 \\
Rainforest & 54 & 2.70 & 0.60 & 0.29 & 9.9 \\
Crop & 30 & 2.50 & 0.45 & 0.27 & 6.36 \\
\hline
\end{tabular}

implementation of a leaf demography scheme (Caldararu et al., 2012) that will allow us to account for the effects of leaf age on the isoprene emission, which has implications for atmospheric chemistry, for instance, timing of the seasonal transition from VOC to $\mathrm{NO}_{\mathrm{x}}$-limited ozone production. We will explore daily and seasonal average isoprene emission model performance using an off-line version of the vegetation model that is driven by meteorology from the GMAO Modern Era-Retrospective Analysis (Rienecker et al., 2011).

We will extend the model to include a photosynthesisbased monoterpene algorithm (Schurgers et al., 2009). A major advantage of the vegetation biophysics in Yale-E2 is the high temporal resolution $(30 \mathrm{~min})$ that will allow additional treatment of monoterpene short-term storage in the mesophyll not considered in any previous studies. The short-term storage may be important in simulating a correct monoterpene emission diurnal cycle.

This study has adopted an isoprene emission model that depends on the electron requirement for isoprene synthesis (Niinemets et al., 1999) necessitating an empirical parameterization of the $\mathrm{CO}_{2}$-inhibition effect. Recently, a simple conceptual model of isoprene emission based on regulation of metabolism in the chloroplast has been proposed (Harrison et al., 2013). This formulation does not require empirical parameterization of the $\mathrm{CO}_{2}$-inhibition effect. The model needs further testing and development before application at the global scale but does hold significant promise of an even more faithful isoprene emission representation for the new generation Earth-system models.

Acknowledgements. Funding for this research was provided by Yale University. This project was supported in part by the facilities and staff of the Yale University Faculty of Arts and Sciences High Performance Computing Center. The authors thank M. Jung, G. Bohrer, W. Munger, A. Friend, E. Blyth, and M. J. Puma. The authors are grateful to the NASA Model-E2 climate model development team who are supported by the NASA Modeling, Analysis and Prediction Program. Harvard Forest flux tower measurements are supported by the US Department of Energy Office of Science and US NSF Long-term Ecological Research program. Edited by: F. McNeill

\section{References}

Affek, H. P., and Yakir, D.: Natural abundance carbon isotope composition of isoprene reflects incomplete coupling between isoprene synthesis and photosynthetic carbon flow, Plant Physiol, 131, 1727-1736, doi:10.1140/Pp.102.012294, 2003.

Arneth, A., Niinemets, Ü., Pressley, S., Bäck, J., Hari, P., Karl, T., Noe, S., Prentice, I. C., Serça, D., Hickler, T., Wolf, A., and Smith, B.: Process-based estimates of terrestrial ecosystem isoprene emissions: incorporating the effects of a direct $\mathrm{CO}_{2}$-isoprene interaction, Atmos. Chem. Phys., 7, 31-53, doi:10.5194/acp-7-31-2007, 2007.

Arneth, A., Monson, R. K., Schurgers, G., Niinemets, Ü., and Palmer, P. I.: Why are estimates of global terrestrial isoprene emissions so similar (and why is this not so for monoterpenes)?, Atmos. Chem. Phys., 8, 4605-4620, doi:10.5194/acp-8-46052008, 2008.

Arneth, A., Unger, N., Kulmala, M., and Andreae, M. O.: Clean the Air, Heat the Planet?, Science, 326, 672-673, doi:10.1126/Science.1181568, 2009.

Arneth, A., Schurgers, G., Lathiere, J., Duhl, T., Beerling, D. J., Hewitt, C. N., Martin, M., and Guenther, A.: Global terrestrial isoprene emission models: sensitivity to variability in climate and vegetation, Atmos. Chem. Phys., 11, 8037-8052, doi:10.5194/acp-11-8037-2011, 2011.

Arneth, A., Mercado, L., Kattge, J., and Booth, B. B. B.: Future challenges of representing land-processes in studies on land-atmosphere interactions, Biogeosciences, 9, 3587-3599, doi:10.5194/bg-9-3587-2012, 2012.

Bai, J. H., Baker, B., Liang, B. S., Greenberg, J., and Guenther, A.: Isoprene and monoterpene emissions from an Inner Mongolia grassland, Atmos. Environ., 40, 5753-5758, doi:10.1016/J.Atmosenv.2006.05.019, 2006.

Baker, B., Bai, J. H., Johnson, C., Cai, Z. T., Li, Q. J., Wang, Y. F., Guenther, A., Greenberg, J., Klinger, L., Geron, C., and Rasmussen, R.: Wet and dry season ecosystem level fluxes of isoprene and monoterpenes from a southeast Asian secondary forest and rubber tree plantation, Atmos. Environ., 39, 381-390, doi:10.1016/J.Atmosenv.2004.07.033, 2005. 
Baldocchi, D.: An Analytical Solution for Coupled Leaf Photosynthesis and Stomatal Conductance Models, Tree Physiol., 14, 1069-1079, 1994.

Baldocchi, D., Falge, E., Gu, L. H., Olson, R., Hollinger, D., Running, S., Anthoni, P., Bernhofer, C., Davis, K., Evans, R., Fuentes, J., Goldstein, A., Katul, G., Law, B., Lee, X. H., Malhi, Y., Meyers, T., Munger, W., Oechel, W., U, K. T. P., Pilegaard, K., Schmid, H. P., Valentini, R., Verma, S., Vesala, T., Wilson, K., and Wofsy, S.: FLUXNET: A new tool to study the temporal and spatial variability of ecosystemscale carbon dioxide, water vapor, and energy flux densities, B. Am. Meteorol. Soc., 82, 2415-2434, doi:10.1175/15200477(2001)082<2415:Fantts>2.3.CO;2, 2001.

Ballantyne, A. P., Alden, C. B., Miller, J. B., Tans, P. P., and White, J. W. C.: Increase in observed net carbon dioxide uptake by land and oceans during the past 50 years, Nature, 488, 70-72, doi:10.1038/Nature11299, 2012.

Barkley, M. P., Palmer, P. I., De Smedt, I., Karl, T., Guenther, A., and Van Roozendael, M.: Regulated large-scale annual shutdown of Amazonian isoprene emissions?, Geophys. Res. Lett., 36, L04803, doi:10.1029/2008gl036843, 2009.

Barkley, M. P., Kurosu, T. P., Chance, K., De Smedt, I., Van Roozendael, M., Arneth, A., Hagberg, D., and Guenther, A.: Assessing sources of uncertainty in formaldehyde air mass factors over tropical South America: Implications for top-down isoprene emission estimates, J. Geophys. Res.-Atmos., 117, D13304, doi:10.1029/2011jd016827, 2012.

Beer, C., Reichstein, M., Tomelleri, E., Ciais, P., Jung, M., Carvalhais, N., Rodenbeck, C., Arain, M. A., Baldocchi, D., Bonan, G. B., Bondeau, A., Cescatti, A., Lasslop, G., Lindroth, A., Lomas, M., Luyssaert, S., Margolis, H., Oleson, K. W., Roupsard, O., Veenendaal, E., Viovy, N., Williams, C., Woodward, F. I., and Papale, D.: Terrestrial Gross Carbon Dioxide Uptake: Global Distribution and Covariation with Climate, Science, 329, 834-838, doi:10.1126/science.1184984, 2010.

Beerling, D. J., Fox, A., Stevenson, D. S., and Valdes, P. J.: Enhanced chemistry-climate feedbacks in past greenhouse worlds, P Natl Acad Sci USA, 108, 9770-9775, doi:10.1073/Pnas.1102409108, 2011.

Behnke, K., Loivamaki, M., Zimmer, I., Rennenberg, H., Schnitzler, J. P., and Louis, S.: Isoprene emission protects photosynthesis in sunfleck exposed Grey poplar, Photosynth. Res., 104, 5-17, doi:10.1007/S11120-010-9528-X, 2010.

Bell, N., Koch, D., and Shindell, D. T.: Impacts of chemistry-aerosol coupling on tropospheric ozone and sulfate simulations in a general circulation model, J. Geophys. Res.-Atmos., 110, D14305, doi:10.1029/2004jd005538, 2005.

Blyth, E., Clark, D. B., Ellis, R., Huntingford, C., Los, S., Pryor, M., Best, M., and Sitch, S.: A comprehensive set of benchmark tests for a land surface model of simultaneous fluxes of water and carbon at both the global and seasonal scale, Geosci. Model. Dev., 4, 255-269, doi:10.5194/gmd-4-255-2011, 2011.

Bonan, G. B., Lawrence, P. J., Oleson, K. W., Levis, S., Jung, M., Reichstein, M., Lawrence, D. M., and Swenson, S. C.: Improving canopy processes in the Community Land Model version 4 (CLM4) using global flux fields empirically inferred from FLUXNET data, J. Geophys. Res.-Biogeosci., 116, G02014, doi:10.1029/2010JG001593, 2011.
Caldararu, S., Palmer, P. I., and Purves, D. W.: Inferring Amazon leaf demography from satellite observations of leaf area index, Biogeosciences, 9, 1389-1404, doi:10.5194/bg-9-13892012, 2012.

Ciais, P., Reichstein, M., Viovy, N., Granier, A., Ogee, J., Allard, V., Aubinet, M., Buchmann, N., Bernhofer, C., Carrara, A., Chevallier, F., De Noblet, N., Friend, A. D., Friedlingstein, P., Grunwald, T., Heinesch, B., Keronen, P., Knohl, A., Krinner, G., Loustau, D., Manca, G., Matteucci, G., Miglietta, F., Ourcival, J. M., Papale, D., Pilegaard, K., Rambal, S., Seufert, G., Soussana, J. F., Sanz, M. J., Schulze, E. D., Vesala, T., and Valentini, R.: Europe-wide reduction in primary productivity caused by the heat and drought in 2003, Nature, 437, 529-533, doi:10.1038/Nature03972, 2005.

Collatz, G. J., Ball, J. T., Grivet, C., and Berry, J. A.: Physiological and Environmental-Regulation of Stomatal Conductance, Photosynthesis and Transpiration - a Model That Includes a Laminar Boundary-Layer, Agr. Forest. Meteorol., 54, 107-136, doi:10.1016/0168-1923(91)90002-8, 1991.

de Noblet-Ducoudre, N., Boisier, J. P., Pitman, A., Bonan, G. B., Brovkin, V., Cruz, F., Delire, C., Gayler, V., van den Hurk, B. J. J. M., Lawrence, P. J., van der Molen, M. K., Muller, C., Reick, C. H., Strengers, B. J., and Voldoire, A.: Determining Robust Impacts of Land-Use-Induced Land Cover Changes on Surface Climate over North America and Eurasia: Results from the First Set of LUCID Experiments, J. Climate, 25, 3261-3281, doi:10.1175/Jcli-D-11-00338.1, 2012.

Delwiche, C. F. and Sharkey, T. D.: Rapid Appearance of C13 in Biogenic Isoprene When $\left(\mathrm{CO}_{2}\right)-\mathrm{C}_{13}$ Is Fed to Intact Leaves, Plant Cell Environ, 16, 587-591, doi:10.1111/J.13653040.1993.Tb00907.X, 1993.

Farquhar, G. D., Caemmerer, S. V., and Berry, J. A.: A BiochemicalModel of Photosynthetic $\mathrm{CO}_{2}$ Assimilation in Leaves of C-3 Species, Planta, 149, 78-90, 1980.

Fiore, A. M., Naik, V., Spracklen, D. V., Steiner, A., Unger, N., Prather, M., Bergmann, D., Cameron-Smith, P. J., Cionni, I., Collins, W. J., Dalsoren, S., Eyring, V., Folberth, G. A., Ginoux, P., Horowitz, L. W., Josse, B., Lamarque, J. F., MacKenzie, I. A., Nagashima, T., O’Connor, F. M., Righi, M., Rumbold, S. T., Shindell, D. T., Skeie, R. B., Sudo, K., Szopa, S., Takemura, T., and Zeng, G.: Global air quality and climate, Chem. Soc. Rev., 41, 6663-6683, doi:10.1039/C2cs35095e, 2012.

Friend, A. D. and Kiang, N. Y.: Land surface model development for the GISS GCM: Effects of improved canopy physiology on simulated climate, J. Climate, 18, 2883-2902, 2005.

Fuentes, J. D., Wang, D., and Gu, L.: Seasonal variations in isoprene emissions from a boreal aspen forest, Journal of Applied Meteorology, 38, 855-869, doi:10.1175/15200450(1999)038<0855:Sviief > 2.0.CO;2, 1999.

Geron, C., Guenther, A., Greenberg, J., Loescher, H. W., Clark, D., and Baker, B.: Biogenic volatile organic compound emissions from a lowland tropical wet forest in Costa Rica, Atmos. Environ., 36, 3793-3802, Pii S1352-2310(02)00301-1, doi:10.1016/S1352-2310(02)00301-1, 2002.

Graus, M., Hansel, A., Wisthaler, A., Lindinger, C., Forkel, R., Hauff, K., Klauer, M., Pfichner, A., Rappengluck, B., Steigner, D., and Steinbrecher, R.: A relaxed-eddyaccumulation method for the measurement of isoprenoid canopy-fluxes using an online gas-chromatographic technique 
and PTR-MS simultaneously, Atmos. Environ., 40, S43-S54, doi:10.1016/J.Atmosenv.2005.09.094, 2006.

Greenberg, J. P., Guenther, A. B., Madronich, S., Baugh, W., Ginoux, P., Druilhet, A., Delmas, R., and Delon, C.: Biogenic volatile organic compound emissions in central Africa during the Experiment for the Regional Sources and Sinks of Oxidants (EXPRESSO) biomass burning season, J. Geophys. Res.-Atmos., 104, 30659-30671, doi:10.1029/1999jd900475, 1999.

Goldstein, A. H., Goulden, M. L., Munger, J. W., Wofsy, S. C., and Geron, C. D.: Seasonal course of isoprene emissions from a midlatitude deciduous forest, J. Geophys. Res.-Atmos., 103, 3104531056, 1998.

Grinspoon, J., Bowman, W. D., and Fall, R.: Delayed Onset of Isoprene Emission in Developing Velvet Bean (Mucuna Sp) Leaves, Plant Physiol., 97, 170-174, doi:10.1104/Pp.97.1.170, 1991.

Guenther, A., Hewitt, C. N., Erickson, D., Fall, R., Geron, C., Graedel, T., Harley, P., Klinger, L., Lerdau, M., Mckay, W. A., Pierce, T., Scholes, B., Steinbrecher, R., Tallamraju, R., Taylor, J., and Zimmerman, P.: A Global-Model of Natural Volatile Organic-Compound Emissions, J. Geophys. Res.-Atmos., 100, 8873-8892, doi:10.1029/94JD02950, 1995.

Guenther, A., Karl, T., Harley, P., Wiedinmyer, C., Palmer, P. I., and Geron, C.: Estimates of global terrestrial isoprene emissions using MEGAN (Model of Emissions of Gases and Aerosols from Nature), Atmos. Chem. Phys., 6, 3181-3210, doi:10.5194/acp-63181-2006, 2006.

Guenther, A. B., Monson, R. K., and Fall, R.: Isoprene and Monoterpene Emission Rate Variability - Observations with Eucalyptus and Emission Rate Algorithm Development, J. Geophys. Res.-Atmos., 96, 10799-10808, doi:10.1029/91JD00960, 1991.

Guenther, A. B., Jiang, X., Heald, C. L., Sakulyanontvittaya, T., Duhl, T., Emmons, L. K., and Wang, X.: The Model of Emissions of Gases and Aerosols from Nature version 2.1 (MEGAN2.1): an extended and updated framework for modeling biogenic emissions, Geosci. Model. Dev., 5, 1471-1492, doi:10.5194/gmd-51471-2012, 2012.

Hakola, H., Rinne, J., and Laurila, T.: The hydrocarbon emission rates of tea-leafed willow (Salix phylicifolia), silver birch (Betula pendula) and European aspen (Populus tremula), Atmos. Environ., 32, 1825-1833, doi:10.1016/S1352-2310(97)00482-2, 1998.

Hanninen, H. and Kramer, K.: A framework for modelling the annual cycle of trees in boreal and temperate regions, Silva Fenn., 41, 167-205, 2007.

Harley, P., Otter, L., Guenther, A., and Greenberg, J.: Micrometeorological and leaf-level measurements of isoprene emissions from a southern African savanna, J. Geophys. Res.-Atmos., 108, 8468, doi:10.1029/2002jd002592, 2003.

Harrison, S. P., Morfopoulos, C., Dani, K. G. S., Prentice, I. C., Arneth, A., Atwell, B. J., Barkley, M. P., Leishman, M. R., Loreto, F., Medlyn, B. E., Niinemets, U., Possell, M., Penuelas, J., and Wright, I. J.: Volatile isoprenoid emissions from plastid to planet, New Phytol., 197, 49-57, doi:10.1111/Nph.12021, 2013.

Heald, C. L., Henze, D. K., Horowitz, L. W., Feddema, J., Lamarque, J. F., Guenther, A., Hess, P. G., Vitt, F., Seinfeld, J. H., Goldstein, A. H., and Fung, I.: Predicted change in global secondary organic aerosol concentrations in response to future cli- mate, emissions, and land use change, J. Geophys. Res.-Atmos., 113, D05211, doi:10.1029/2007jd009092, 2008.

Heald, C. L., Wilkinson, M. J., Monson, R. K., Alo, C. A., Wang, G. L., and Guenther, A.: Response of isoprene emission to ambient $\mathrm{CO}_{2}$ changes and implications for global budgets, Global Change Biol., 15, 1127-1140, doi:10.1111/J.13652486.2008.01802.X, 2009.

Hewitt, C. N., Ashworth, K., Boynard, A., Guenther, A., Langford, B., MacKenzie, A. R., Misztal, P. K., Nemitz, E., Owen, S. M., Possell, M., Pugh, T. A. M., Ryan, A. C., and Wild, O.: Groundlevel ozone influenced by circadian control of isoprene emissions, Nat Geosci., 4, 671-674, doi:10.1038/Ngeo1271, 2011.

Horowitz, L. W., Fiore, A. M., Milly, G. P., Cohen, R. C., Perring, A., Wooldridge, P. J., Hess, P. G., Emmons, L. K., and Lamarque, J. F.: Observational constraints on the chemistry of isoprene nitrates over the eastern United States, J. Geophys. Res.-Atmos., 112, D12S08, doi:10.1029/2006jd007747, 2007.

Hurtt, G. C., Chini, L. P., Frolking, S., Betts, R. A., Feddema, J., Fischer, G., Fisk, J. P., Hibbard, K., Houghton, R. A., Janetos, A., Jones, C. D., Kindermann, G., Kinoshita, T., Goldewijk, K. K., Riahi, K., Shevliakova, E., Smith, S., Stehfest, E., Thomson, A., Thornton, P., van Vuuren, D. P., and Wang, Y. P.: Harmonization of land-use scenarios for the period 1500-2100: 600 years of global gridded annual land-use transitions, wood harvest, and resulting secondary lands, Clim. Change, 109, 117161, doi:10.1007/S10584-011-0153-2, 2011.

Isebrands, J. G., Guenther, A. B., Harley, P., Helmig, D., Klinger, L., Vierling, L., Zimmerman, P., and Geron, C.: Volatile organic compound emission rates from mixed deciduous and coniferous forests in Northern Wisconsin, USA, Atmos. Environ., 33, 2527 2536, doi:10.1016/S1352-2310(98)00250-7, 1999.

Jung, M., Reichstein, M., Margolis, H. A., Cescatti, A., Richardson, A. D., Arain, M. A., Arneth, A., Bernhofer, C., Bonal, D., Chen, J. Q., Gianelle, D., Gobron, N., Kiely, G., Kutsch, W., Lasslop, G., Law, B. E., Lindroth, A., Merbold, L., Montagnani, L., Moors, E. J., Papale, D., Sottocornola, M., Vaccari, F., and Williams, C.: Global patterns of landatmosphere fluxes of carbon dioxide, latent heat, and sensible heat derived from eddy covariance, satellite, and meteorological observations, J. Geophys. Res.-Biogeosci., 116, G00J07, doi:10.1029/2010JG001566, 2011.

Karl, T., Fall, R., Rosenstiel, T. N., Prazeller, P., Larsen, B., Seufert, G., and Lindinger, W.: On-line analysis of the $\left(\mathrm{CO}_{2}\right)-\mathrm{C}_{13}$ labeling of leaf isoprene suggests multiple subcellular origins of isoprene precursors, Planta, 215, 894-905, doi:10.1007/S00425002-0825-2, 2002.

Karl, T., Potosnak, M., Guenther, A., Clark, D., Walker, J., Herrick, J. D., and Geron, C.: Exchange processes of volatile organic compounds above a tropical rain forest: Implications for modeling tropospheric chemistry above dense vegetation, J. Geophys Res.-Atmos., 109, D18306, doi:10.1029/2004JD004738, 2004.

Karl, T. G., Christian, T. J., Yokelson, R. J., Artaxo, P., Hao, W. M., and Guenther, A.: The Tropical Forest and Fire Emissions Experiment: method evaluation of volatile organic compound emissions measured by PTR-MS, FTIR, and GC from tropical biomass burning, Atmos. Chem. Phys., 7, 5883-5897, doi:10.5194/acp-7-5883-2007, 2007.

Kesselmeier, J. and Staudt, M.: Biogenic volatile organic compounds (VOC): An overview on emission, 
physiology and ecology, J. Atmos. Chem., 33, 23-88, doi:10.1023/A:1006127516791, 1999.

Kuhn, U., Andreae, M. O., Ammann, C., Araujo, A. C., Brancaleoni, E., Ciccioli, P., Dindorf, T., Frattoni, M., Gatti, L. V., Ganzeveld, L., Kruijt, B., Lelieveld, J., Lloyd, J., Meixner, F. X., Nobre, A. D., Poschl, U., Spirig, C., Stefani, P., Thielmann, A., Valentini, R., and Kesselmeier, J.: Isoprene and monoterpene fluxes from Central Amazonian rainforest inferred from towerbased and airborne measurements, and implications on the atmospheric chemistry and the local carbon budget, Atmos. Chem. Phys., 7, 2855-2879, doi:10.5194/acp-10-627-2010, 2007.

Kuzma, J. and Fall, R.: Leaf Isoprene Emission Rate Is Dependent on Leaf Development and the Level of Isoprene Synthase, Plant Physiol., 101, 435-440, 1993.

Langford, B., Misztal, P. K., Nemitz, E., Davison, B., Helfter, C., Pugh, T. A. M., MacKenzie, A. R., Lim, S. F., and Hewitt, C. N.: Fluxes and concentrations of volatile organic compounds from a South-East Asian tropical rainforest, Atmos. Chem. Phys., 10, 8391-8412, doi:10.5194/acp-10-8391-2010, 2010a.

Langford, B., Nemitz, E., House, E., Phillips, G. J., Famulari, D., Davison, B., Hopkins, J. R., Lewis, A. C., and Hewitt, C. N.: Fluxes and concentrations of volatile organic compounds above central London, UK, Atmos. Chem. Phys., 10, 627-645, doi:10.5194/acp-10-627-2010, 2010b.

Langenhove, H., Steppe, K., Simpraga, M., and Heinesch, B.: Isoprene and monoterpene emissions from a mixed temperate forest, Atmos. Environ., 45, 3157-3168, doi10.1016/J.Atmosenv.2011.02.054, 2011.

Lathiére, J., Hauglustaine, D. A., Friend, A. D., De NobletDucoudré, N., Viovy, N., and Folberth, G. A.: Impact of climate variability and land use changes on global biogenic volatile organic compound emissions, Atmos. Chem. Phys., 6, 2129-2146, doi:10.5194/acp-6-2129-2006, 2006.

Law, B. E., Falge, E., Gu, L., Baldocchi, D. D., Bakwin, P., Berbigier, P., Davis, K., Dolman, A. J., Falk, M., Fuentes, J. D., Goldstein, A., Granier, A., Grelle, A., Hollinger, D., Janssens, I. A., Jarvis, P., Jensen, N. O., Katul, G., Mahli, Y., Matteucci, G., Meyers, T., Monson, R., Munger, W., Oechel, W., Olson, R., Pilegaard, K., Paw, K. T., Thorgeirsson, H., Valentini, R., Verma, S., Vesala, T., Wilson, K., and Wofsy, S.: Environmental controls over carbon dioxide and water vapor exchange of terrestrial vegetation, Agr. Forest Meteorol., 113, 97-120, doi:10.1016/S01681923(02)00104-1, 2002.

Loreto, F. and Schnitzler, J. P.: Abiotic stresses and induced BVOCs, Trend. Plant Sci., 15, 154-166, doi:10.1016/J.Tplants.2009.12.006, 2010.

Loveland, T., J. Brown, D. Ohlen, B. Reed, Z. Zhu, L. Yang, S. Howard.: ISLSCP II IGBP DISCover and SiB Land Cover, 1992-1993, ISLSCP Initiative II Collection, available online: http://daac.ornl.gov/ from Oak Ridge National Laboratory Distributed Active Archive Center, Oak Ridge, Tennessee, USA, doi:10.3334/ORNLDAAC/930, 2009.

Makela, A., Hari, P., Berninger, F., Hanninen, H., and Nikinmaa, E.: Acclimation of photosynthetic capacity in Scots pine to the annual cycle of temperature, Tree Physiol., 24, 369-376, 2004.

Matthews, E.: Global Vegetation and Land-Use - New High-Resolution Data-Bases for Climate Studies, J. Clim. Appl. Meteorol., 22, 474-487, doi:10.1175/15200450(1983)022<0474:Gvalun>2.0.CO;2, 1983.
McKinney, K. A., Lee, B. H., Vasta, A., Pho, T. V., and Munger, J. W.: Emissions of isoprenoids and oxygenated biogenic volatile organic compounds from a New England mixed forest, Atmos. Chem. Phys., 11, 4807-4831, doi:10.5194/acp-11-4807-2011, 2011.

Migliavacca, M., Sonnentag, O., Keenan, T. F., Cescatti, A., O'Keefe, J., and Richardson, A. D.: On the uncertainty of phenological responses to climate change, and implications for a terrestrial biosphere model, Biogeosciences, 9, 2063-2083, doi:10.5194/bg-9-2063-2012, 2012.

Milla, R. and Reich, P. B.: The scaling of leaf area and mass: the cost of light interception increases with leaf size, Proc. Res. Soc. B, 274, 2109-2114, doi:10.1098/Rspb.2007.0417, 2007.

Monfreda, C., Ramankutty, N., and Foley, J. A.: Farming the planet: 2. Geographic distribution of crop areas, yields, physiological types, and net primary production in the year 2000, Global Biogeochem. Cy., 22, GB1022 doi:10.1029/2007GB002947, 2008.

Monson, R. K., Harley, P. C., Litvak, M. E., Wildermuth, M., Guenther, A. B., Zimmerman, P. R., and Fall, R.: Environmental and Developmental Controls over the Seasonal Pattern of Isoprene Emission from Aspen Leaves, Oecologia, 99, 260-270, 1994.

Monson, R. K., Trahan, N., Rosenstiel, T. N., Veres, P., Moore, D., Wilkinson, M., Norby, R. J., Volder, A., Tjoelker, M. G., Briske, D. D., Karnosky, D. F., and Fall, R.: Isoprene emission from terrestrial ecosystems in response to global change: minding the gap between models and observations, Philos. T. R. Soc. A, 365, 1677-1695, doi:10.1098/Rsta.2007.2038, 2007.

Müller, J.-F., Stavrakou, T., Wallens, S., De Smedt, I., Van Roozendael, M., Potosnak, M. J., Rinne, J., Munger, B., Goldstein, A., and Guenther, A. B.: Global isoprene emissions estimated using MEGAN, ECMWF analyses and a detailed canopy environment model, Atmos. Chem. Phys., 8, 1329-1341, doi:10.5194/acp-81329-2008, 2008.

Niinemets, U.: Mild versus severe stress and BVOCs: thresholds, priming and consequences, Trends Plant. Sci., 15, 145-153, doi:10.1016/J.Tplants.2009.11.008, 2010.

Niinemets, U., Tenhunen, J. D., Harley, P. C., and Steinbrecher, R.: A model of isoprene emission based on energetic requirements for isoprene synthesis and leaf photosynthetic properties for Liquidambar and Quercus, Plant Cell Environ., 22, 13191335, 1999.

Niinemets, U., Arneth, A., Kuhn, U., Monson, R. K., Penuelas, J., and Staudt, M.: The emission factor of volatile isoprenoids: stress, acclimation, and developmental responses, Biogeosciences, 7, 2203-2223, doi:10.5194/bg-7-2203-2010, 2010a.

Niinemets, U., Copolovici, L., and Huve, K.: High withincanopy variation in isoprene emission potentials in temperate trees: Implications for predicting canopy-scale isoprene fluxes, J. Geophys. Res.-Biogeosci., 115, G04029 doi:10.1029/2010JG001436, 2010b.

Niinemets, U., Monson, R. K., Arneth, A., Ciccioli, P., Kesselmeier, J., Kuhn, U., Noe, S. M., Penuelas, J., and Staudt, M.: The leaflevel emission factor of volatile isoprenoids: caveats, model algorithms, response shapes and scaling, Biogeosciences, 7, 18091832, doi:10.5194/bg-7-1809-2010, 2010c.

Oleson, K. W., Lawrence, D. M., Bonan, G. B., Flanne, M. G., Kluzek, E., Lawrence, P. J., Levis, S., Swenson, S. C., and Thronton, P. E.: Technical Description of version 4.0 of the Community 
Land Model (CLM), National Center for Atmospheric Research, Boulder, CONCAR/TN-478+STR, 2010.

Olofsson, M., Ek-Olausson, B., Jensen, N. O., Langer, S., and Ljungstrom, E.: The flux of isoprene from a willow coppice plantation and the effect on local air quality, Atmos. Environ., 39, 2061-2070, doi:10.1016/J.Atmosenv.2004.12.015, 2005.

Pacifico, F., Harrison, S. P., Jones, C. D., Arneth, A., Sitch, S., Weedon, G. P., Barkley, M. P., Palmer, P. I., Serca, D., Potosnak, M., Fu, T. M., Goldstein, A., Bai, J., and Schurgers, G.: Evaluation of a photosynthesis-based biogenic isoprene emission scheme in JULES and simulation of isoprene emissions under presentday climate conditions, Atmos. Chem. Phys., 11, 4371-4389, doi:10.5194/acp-11-4371-2011, 2011.

Pacifico, F., Folberth, G. A., Jones, C. D., Harrison, S. P., and Collins, W. J.: Sensitivity of biogenic isoprene emissions to past, present, and future environmental conditions and implications for atmospheric chemistry, J. Geophys. Res.-Atmos., 117, D22302, doi:10.1029/2012jd018276, 2012.

Palmer, P. I., Jacob, D. J., Fiore, A. M., Martin, R. V., Chance, K., and Kurosu, T. P.: Mapping isoprene emissions over North America using formaldehyde column observations from space, J. Geophys. Res.-Atmos., 108, 4180, doi:10.1029/2002jd002153, 2003.

Pattey, E., Desjardins, R. L., Westberg, H., Lamb, B., and Zhu, T.: Measurement of isoprene emissions over a black spruce stand using a tower-based relaxed eddy-accumulation system, J. Appl. Meteorol., 38, 870-877, doi:10.1175/15200450(1999)038<0870:Moieoa>2.0.CO;2, 1999.

Pegoraro, E., Rey, A., Greenberg, J., Harley, P., Grace, J., Malhi, Y., and Guenther, A.: Effect of drought on isoprene emission rates from leaves of Quercus virginiana Mill., Atmos. Environ., 38, 6149-6156, doi:10.1016/J.Atmosenv.2004.07.028, 2004.

Pegoraro, E., Rey, A., Barron-Gafford, G., Monson, R., Malhi, Y., and Murthy, R.: The interacting effects of elevated atmospheric $\mathrm{CO}_{2}$ concentration, drought and leaf-to-air vapour pressure deficit on ecosystem isoprene fluxes, Oecologia, 146, 120129, doi:10.1007/S00442-005-0166-5, 2005.

Pegoraro, E., Rey, A., Abrell, L., Vanharen, J., and Lin, G. H.: Drought effect on isoprene production and consumption in Biosphere 2 tropical rainforest, Global Change Biol, 12, 456-469, doi:10.1111/J.1365-2486.2006.01112.X, 2006.

Pfister, G. G., Emmons, L. K., Hess, P. G., Lamarque, J. F., Orlando, J. J., Walters, S., Guenther, A., Palmer, P. I., and Lawrence, P. J.: Contribution of isoprene to chemical budgets: A model tracer study with the NCAR CTM MOZART-4, J. Geophys. Res.-Atmos., 113, D05308, doi:10.1029/2007jd008948, 2008.

Pitman, A. J., Arneth, A., and Ganzeveld, L.: Regionalizing global climate models, Int. J. Climatol., 32, 321-337, doi:10.1002/Joc.2279, 2012.

Porporato, A., Laio, F., Ridolfi, L., and Rodriguez-Iturbe, I.: Plants in water-controlled ecosystems: active role in hydrologic processes and response to water stress - III. Vegetation water stress, Adv. Water Resour., 24, 725-744, doi:10.1016/S03091708(01)00006-9, 2001.

Possell, M., Heath, J., Nicholas Hewitt, C., Ayres, E., and Kerstiens, G.: Interactive effects of elevated $\mathrm{CO}_{2}$ and soil fertility on isoprene emissions from Quercus robur, Global Change Biol., 10, 1835-1843, doi:10.1111/J.1365-2486.2004.00845.X, 2004.

Possell, M., Hewitt, C. N., and Beerling, D. J.: The effects of glacial atmospheric $\mathrm{CO}_{2}$ concentrations and climate on isoprene emissions by vascular plants, Global Change Biol., 11, 60-69, doi:10.1111/J.1365-2486.2004.00889.X, 2005.

Possell, M. and Hewitt, C. N.: Isoprene emissions from plants are mediated by atmospheric $\mathrm{CO}_{2}$ concentrations, Global Change Biol., 17, 1595-1610, doi:10.1111/J.1365-2486.2010.02306.X, 2011.

Potosnak, M. J., Baker, B. M., LeStourgeon, L., Disher, S. M., Griffin, K. L., Bret-Harte, M. S., and Starr, G.: Isoprene emissions from a tundra ecosystem, Biogeosciences, 10, 871-889, doi:10.5194/bg-10-871-2013, 2013.

Pressley, S., Lamb, B., Westberg, H., Flaherty, J., Chen, J., and Vogel, C.: Long-term isoprene flux measurements above a northern hardwood forest, J. Geophys. Res.-Atmos., 110, D07301, doi:10.1029/2004jd005523, 2005.

Rayner, N. A., Brohan, P., Parker, D. E., Folland, C. K., Kennedy, J. J., Vanicek, M., Ansell, T. J., and Tett, S. F. B.: Improved analyses of changes and uncertainties in sea surface temperature measured in situ sice the mid-nineteenth century: The HadSST2 dataset, J. Climate, 19, 446-469, doi:10.1175/Jcli3637.1, 2006.

Richardson, A. D., Keenan, T. F., Migliavacca, M., Ryu, Y., Sonnentag, O., and Toomey, M.: Climate change, phenology, and phenological control of vegetation feedbacks to the climate system, Agr. Forest Meteorol., 169, 156-173, doi:10.1016/J.Agrformet.2012.09.012, 2013.

Rienecker, M. M., Suarez, M. J., Gelaro, R., Todling, R., Bacmeister, J., Liu, E., Bosilovich, M. G., Schubert, S. D., Takacs, L., Kim, G. K., Bloom, S., Chen, J. Y., Collins, D., Conaty, A., Da Silva, A., Gu, W., Joiner, J., Koster, R. D., Lucchesi, R., Molod, A., Owens, T., Pawson, S., Pegion, P., Redder, C. R., Reichle, R., Robertson, F. R., Ruddick, A. G., Sienkiewicz, M., and Woollen, J.: MERRA: NASA's Modern-Era Retrospective Analysis for Research and Applications, J. Climate, 24, 3624-3648, doi:10.1175/Jcli-D-11-00015.1, 2011.

Rinne, H. J. I., Guenther, A. B., Greenberg, J. P., and Harley, P. C.: Isoprene and monoterpene fluxes measured above Amazonian rainforest and their dependence on light and temperature, Atmos Environ, 36, 2421-2426, Pii S1352-2310(01)00523-4, 2002.

Rinne, J., Back, J., and Hakola, H.: Biogenic volatile organic compound emissions from the Eurasian taiga: current knowledge and future directions, Boreal Environ. Res., 14, 807-826, 2009.

Rinne, J., Markkanen, T., Ruuskanen, T. M., Petaja, T., Keronen, P., Tang, M. J., Crowley, J. N., Rannik, U., and Vesala, T.: Effect of chemical degradation on fluxes of reactive compounds - a study with a stochastic Lagrangian transport model, Atmos. Chem. Phys., 12, 4843-4854, doi:10.5194/acp-12-4843-2012, 2012.

Rosenstiel, T. N., Potosnak, M. J., Griffin, K. L., Fall, R., and Monson, R. K.: Increased $\mathrm{CO}_{2}$ uncouples growth from isoprene emission in an agriforest ecosystem, Nature, 421, 256-259, doi:10.1038/Nature01312, 2003.

Rosenzweig, C. and Abramopoulos, F.: Land-surface model development for the GISS GCM, J Climate, 10, 2040-2054, doi:10.1175/1520-0442(1997)010<2040:Lsmdft>2.0.CO;2, 1997.

Sacks, W. J., Deryng, D., Foley, J. A., and Ramankutty, N.: Crop planting dates: an analysis of global patterns, Global Ecology and Biogeography, 19, 607-620, doi:10.1111/J.14668238.2010.00551.X, 2010.

Saito, T., Yokouchi, Y., Kosugi, Y., Tani, M., Philip, E., and Okuda, T.: Methyl chloride and isoprene emissions from tropical 
rain forest in Southeast Asia, Geophys. Res. Lett., 35, L19812, doi:10.1029/2008g1035241, 2008.

Schmidt, G. A., Ruedy, R., Hansen, J. E., Aleinov, I., Bell, N., Bauer, M., Bauer, S., Cairns, B., Canuto, V., Cheng, Y., Del Genio, A., Faluvegi, G., Friend, A. D., Hall, T. M., Hu, Y. Y., Kelley, M., Kiang, N. Y., Koch, D., Lacis, A. A., Lerner, J., Lo, K. K., Miller, R. L., Nazarenko, L., Oinas, V., Perlwitz, J., Perlwitz, J., Rind, D., Romanou, A., Russell, G. L., Sato, M., Shindell, D. T., Stone, P. H., Sun, S., Tausnev, N., Thresher, D., and Yao, M. S.: Present-day atmospheric simulations using GISS ModelE: Comparison to in situ, satellite, and reanalysis data, J. Climate, 19, 153-192, 2006.

Schurgers, G., Arneth, A., Holzinger, R., and Goldstein, A. H.: Process-based modelling of biogenic monoterpene emissions combining production and release from storage, Atmos. Chem. Phys., 9, 3409-3423, doi:10.5194/acp-9-3409-2009, 2009.

Schurgers, G., Arneth, A., and Hickler, T.: Effect of climate-driven changes in species composition on regional emission capacities of biogenic compounds, J. Geophys. Res.-Atmos., 116, D22304, doi:10.1029/2011jd016278, 2011.

Schwalm, C. R., Williams, C. A., Schaefer, K., Anderson, R., Arain, M. A., Baker, I., Barr, A., Black, T. A., Chen, G. S., Chen, J. M., Ciais, P., Davis, K. J., Desai, A., Dietze, M., Dragoni, D., Fischer, M. L., Flanagan, L. B., Grant, R., Gu, L. H., Hollinger, D., Izaurralde, R. C., Kucharik, C., Lafleur, P., Law, B. E., Li, L. H., Li, Z. P., Liu, S. G., Lokupitiya, E., Luo, Y. Q., Ma, S. Y., Margolis, H., Matamala, R., McCaughey, H., Monson, R. K., Oechel, W. C., Peng, C. H., Poulter, B., Price, D. T., Riciutto, D. M., Riley, W., Sahoo, A. K., Sprintsin, M., Sun, J. F., Tian, H. Q., Tonitto, C., Verbeeck, H., and Verma, S. B.: A model-data intercomparison of $\mathrm{CO}_{2}$ exchange across North America: Results from the North American Carbon Program site synthesis, J. Geophys. Res.Biogeosci., 115, G00H05 doi:10.1029/2009jg001229, 2010.

Serca, D., Guenther, A., Klinger, L., Vierling, L., Harley, P., Druilhet, A., Greenberg, J., Baker, B., Baugh, W., Bouka-Biona, C., and Loemba-Ndembi, J.: EXPRESSO flux measurements at upland and lowland Congo tropical forest site, Tellus B, 53, 220234, 2001.

Sharkey, T. D. and Loreto, F.: Water-Stress, Temperature, and Light Effects on Isoprene Emission and Photosynthesis of Kudzu Leaves, Plant Physiol., 102, 159-159, 1993.

Sharkey, T. D. and Singsaas, E. L.: Why Plants Emit Isoprene, Nature, 374, 769-769, doi:10.1038/374769a0, 1995.

Shindell, D. T., Faluvegi, G., Unger, N., Aguilar, E., Schmidt, G. A., Koch, D. M., Bauer, S. E., and Miller, R. L.: Simulations of preindustrial, present-day, and 2100 conditions in the NASA GISS composition and climate model G-PUCCINI, Atmos. Chem. Phys., 6, 4427-4459, doi:10.5194/acp-6-4427-2006, 2006.

Shindell, D. T., Pechony, O., Voulgarakis, A., Faluvegi, G., Nazarenko, L., Lamarque, J. F., Bowman, K., Milly, G., Kovari, B., Ruedy, R., and Schmidt, G. A.: Interactive ozone and methane chemistry in GISS-E2 historical and future climate simulations, Atmos. Chem. Phys., 13, 2653-2689, doi:10.5194/acp-13-26532013, 2013.

Sitch, S., Huntingford, C., Gedney, N., Levy, P. E., Lomas, M., Piao, S. L., Betts, R., Ciais, P., Cox, P., Friedlingstein, P., Jones, C. D., Prentice, I. C., and Woodward, F. I.: Evaluation of the terrestrial carbon cycle, future plant geography and climate-carbon cycle feedbacks using five Dynamic Global Vegetation Models (DGVMs), Global Change Biol., 14, 2015-2039, doi:10.1111/J.1365-2486.2008.01626.X, 2008.

Spirig, C., Guenther, A., Greenberg, J. P., Calanca, P., and Tarvainen, V.: Tethered balloon measurements of biogenic volatile organic compounds at a Boreal forest site, Atmos. Chem. Phys., 4, 215-229, 2004,

http://www.atmos-chem-phys.net/4/215/2004/.

Spirig, C., Neftel, A., Ammann, C., Dommen, J., Grabmer, W., Thielmann, A., Schaub, A., Beauchamp, J., Wisthaler, A., and Hansel, A.: Eddy covariance flux measurements of biogenic VOCs during ECHO 2003 using proton transfer reaction mass spectrometry, Atmos. Chem. Phys., 5, 465-481, 2005, http://www.atmos-chem-phys.net/5/465/2005/.

Steinbrecher, R., Klauer, M., Hauff, K., Stockwell, W. R., Jaeschke, W., Dietrich, T., and Herbert, F.: Biogenic and anthropogenic fluxes of non-methane hydrocarbons over an urbanimpacted forest, Frankfurter Stadtwald, Germany, Atmos. Environ., 34, 37793788, doi:10.1016/S1352-2310(99)00518-X, 2000.

Toivonen, A., Rikala, R., Repo, T., and Smolander, H.: Autumn Colouration of First Year Pinus sylvestris Seedlings during Frost Hardening, Scand. J. Forest Res., 6, 31-39, doi:10.1080/02827589109382644, 1991.

Unger, N.: Global climate impact of civil aviation for standard and desulfurized jet fuel, Geophys. Res. Lett., 38, L20803, doi:10.1029/2011GL049289, 2011.

Vickers, C. E., Gershenzon, J., Lerdau, M. T., and Loreto, F.: A unified mechanism of action for volatile isoprenoids in plant abiotic stress, Nat. Chem. Biol., 5, 283-291, doi:10.1038/Nchembio.158, 2009.

von Caemmerer, S. and Farquhar, G. D.: Some Relationships between the Biochemistry of Photosynthesis and the Gas-Exchange of Leaves, Planta, 153, 3, 1981

Warneke, C., de Gouw, J. A., Del Negro, L., Brioude, J., McKeen, S., Stark, H., Kuster, W. C., Goldan, P. D., Trainer, M., Fehsenfeld, F. C., Wiedinmyer, C., Guenther, A. B., Hansel, A., Wisthaler, A., Atlas, E., Holloway, J. S., Ryerson, T. B., Peischl, J., Huey, L. G., and Hanks, A. T. C.: Biogenic emission measurement and inventories determination of biogenic emissions in the eastern United States and Texas and comparison with biogenic emission inventories, J. Geophys. Res.-Atmos., 115, D00F18, doi:10.1029/2009jd012445, 2010.

Way, D. A., Schnitzler, J. P., Monson, R. K., and Jackson, R. B.: Enhanced isoprene-related tolerance of heat- and light-stressed photosynthesis at low, but not high, $\mathrm{CO}_{2}$ concentrations, Oecologia, 166, 273-282, doi:10.1007/S00442-011-1947-7, 2011.

Welp, L. R., Keeling, R. F., Meijer, H. A. J., Bollenbacher, A. F., Piper, S. C., Yoshimura, K., Francey, R. J., Allison, C. E., and Wahlen, M.: Interannual variability in the oxygen isotopes of atmospheric $\mathrm{CO}_{2}$ driven by El Nino, Nature, 477, 579-582, doi:10.1038/Nature10421, 2011.

Westberg, H., Lamb, B., Hafer, R., Hills, A., Shepson, P., and Vogel, C.: Measurement of isoprene fluxes at the PROPHET site, J. Geophys. Res.-Atmos., 106, 24347-24358, doi:10.1029/2000JD900735, 2001.

Wilkinson, M. J., Monson, R. K., Trahan, N., Lee, S., Brown, E., Jackson, R. B., Polley, H. W., Fay, P. A., and Fall, R.: Leaf isoprene emission rate as a function of atmospheric $\mathrm{CO}_{2}$ concentra- 
tion, Global Change Biol., 15, 1189-1200, doi:10.1111/J.13652486.2008.01803.X, 2009.

Wu, S. L., Mickley, L. J., Leibensperger, E. M., Jacob, D. J., Rind, D., and Streets, D. G.: Effects of 2000-2050 global change on ozone air quality in the United States, J. Geophys. Res.-Atmos., 113, D06302, doi:10.1029/2007JD008917, 2008.

Young, P. J., Arneth, A., Schurgers, G., Zeng, G., and Pyle, J. A.: The $\mathrm{CO} 2$ inhibition of terrestrial isoprene emission significantly affects future ozone projections, Atmos. Chem. Phys., 9, 27932803, doi:10.5194/acp-9-2793-2009, 2009.

Young, P. J., Archibald, A. T., Bowman, K. W., Lamarque, J. F., Naik, V., Stevenson, D. S., Tilmes, S., Voulgarakis, A., Wild, O., Bergmann, D., Cameron-Smith, P., Cionni, I., Collins, W. J., Dalsoren, S. B., Doherty, R. M., Eyring, V., Faluvegi, G., Horowitz, L. W., Josse, B., Lee, Y. H., MacKenzie, I. A., Nagashima, T., Plummer, D. A., Righi, M., Rumbold, S. T., Skeie, R. B., Shindell, D. T., Strode, S. A., Sudo, K., Szopa, S., and Zeng, G.: Preindustrial to end 21 st century projections of tropospheric ozone from the Atmospheric Chemistry and Climate Model Intercomparison Project (ACCMIP), Atmos. Chem. Phys., 13, 20632090, doi:10.5194/acp-13-2063-2013, 2013. 